\title{
やさしい日本語ニュースの制作支援システム
}

\author{
田中 英輝 ${ }^{\dagger}$ 熊野正 ${ }^{\dagger}$ 後藤 功雄 ${ }^{\dagger} \cdot$ 美野 秀弥 $^{\dagger}$
}

NHK はインターネットサイト NEWS WEB EASY で外国人を対象としたやさしい 日本語のニュースを提供している。 やさしい日本語のニュースは日本語教師と記者 の 2 名が通常のニュースを共同でやさしく書き換えて制作し，本文にはふりがな， 難しい語への辞書といった読解補助情報が付与されている。本稿では NEWS WEB EASY のやさしい日本語の書き換え原則, および制作の体制とプロセスの概要と課 題を説明した後, 課題に対処するために開発した 2 つのエディタを説明する． 1 つ は書き換えを支援する「書き換えエディタ」である。書き換えエディタは先行のシ ステムと同様に難しい語を指摘し，書き換え候補を提示する機能を持つが，2 名以 上の共同作業を支援する点，難しい語の指摘機能に学習機能を持つ点，また，候補 の提示に書き換え事例を蓄積して利用する点に特徵がある。他の 1 つは「読解補助 情報エディ夕」である。読解補助情報エディタは，ふりがなや辞書情報を自動推定 する機能，さらに推定誤りの修正結果を学習する機能を持つ. 以上のように 2 つの エディタは, 自動学習と用例の利用により, 読解補助情報の推定の誤り, やさしい 日本語の書き方の方針変更などに日々の運用の中で自律的に対応できるようになっ ている。本稿では 2 つのエデイ夕の詳細説明の後, 日本語教師および記者を対象に 実施したアンケート調査，およびログ解析によりエディタの有効性を示す.

キーワード：やさしい日本語, NEWS WEB EASY, 書き換え支援システム, 機械学習

\section{Rewrite Support System for Simplifying Japanese News Scripts}

\author{
Hideki TANaka ${ }^{\dagger}$, Tadashi Kumano ${ }^{\dagger}$, Isao Goto ${ }^{\dagger}$ and Hideya Mino ${ }^{\dagger}$
}

NHK launched a simplified Japanese news service on the Internet (NEWS WEB EASY) in April 2012 to improve news accessibility for foreign residents in Japan. Simplified news scripts are compiled daily by a Japanese language instructor and a news reporter working together using a custom news rewrite support system comprising a rewrite support editor and a reading support information editor. The rewrite support editor identifies difficult expressions and proposes simpler alternatives with similar expression search function, and the reading support information editor helps the Japanese language instructor add auxiliary information such as furigana and glossary information to the simplified news scripts. Both functions feature learning mechanisms that improve the precision of news simplification. This news rewrite support

† NHK 放送技術研究所, NHK Science and Technology Research Laboratories 
system has been in daily use since 2012. A questionnaire evaluation administered to the Japanese instructors and reporters who produce NEWS WEB EASY showed that they highly evaluated both editors. Analysis of the rewrite support editor's log revealed that the difficult word rate and sentence length in the rewritten news were less than in the original and were similar across rewriters.

Key Words: Simplified Japanese, NEWS WEB EASY, Japanese Text Simplification Support System, Machine Learning

\section{1 はじめに}

法務省の統計によれば日本の在留外国人数は第 2 次世界大戦以後, 基本的に増加傾向にあり 2016 年 12 月には 238 万人，総人口の約 $1.9 \%$ 占めるに至っている．外国人の比率は欧米諸国 と比較して必ずしも高いとは言えないが，東京都新宿区では外国人の比率が $10 \%$ 超えるなど， 日本でも大都市部などで欧米諸国並みの集中が発生している，日本人 1 と同等に日本語が使える 国内在住の外国人は少数であり，彼らへの適切な情報提供は大きな課題となっている.

外国人へはそれぞれの母語で情報を提供するのが理想である，実際，母語を使ったサービス はすでに多言語サービスの中で一部実現されており，例えば NHK は現在国内向けに 5 言語で ニュースを放送している2。 しかし母語での情報提供は 10 言語程度にとどまることが多く，国 内の外国人の出身国数が 190 に達する状況に対応するには十分とは言えない.とはいえ外国人 の全員をカバーするには膨大な数の翻訳が必要となり，コストや労力の大きさから実現は難し い(河原, 野山 2007).

そこで母語ではなく，外国人に分かりやすい「やさしい日本語」で情報を伝えようという考 え方が提唱されている (佐藤 2004; 庵, 岩田, 森 2009). その背景には, やさしい日本語を理解 できる外国人が多いこと (岩田 2010), 外国人の中からも母語の他にやさしい日本語による情報 提供を望む声が上がっていることなどがある (米倉, 谷 2012).

以上の背景の中，NHK は一般のニュースをやさしい日本語で提供できれば，外国人への有 用な情報提供になると考えて研究を進め, 2012 年 4 月から Web でのサービス「NEWS WEB EASY」3 を開始した。 外国人に日本語でニュースを提供しょうとする NEWS WEB EASYと 同様のサービスは当時例がなく，著者らはまずやさしい日本語の作り方の原則を決め, Webで 提供する内容を決めた。 また書き換え作業にはやさしい日本語とニュース編集の知識が必要な ことから日本語教師と記者の共同で進めることにした。

\footnotetext{
1 本稿では便宜的に日本語母語話者を日本人と呼ぶ。また日本に一定期間以上居住する日本語非母語話者を外国人と 呼ぶ.

2 英語, 中国語, 韓国語, スペイン語, ポルトガル語

${ }^{3}$ http://www3.nhk.or.jp/news/easy/index.html
} 
方針の決定と並行して，日々の作業を円滑に進めるための支援システムを開発することにし たが，先行事例がそしく明確にその仕様を決めることはできなかった，そこでプロトタイピン グの手法 (Pressman 2005) を採用し，とりあえず有効と思われる機能をできるだけ早く実装し, 作業者の要望に応じて改善を加えることにした，以上の過程で作成したのが，日本語教師と記 者の共同のニュースの書き換えを支援する「書き換えエディタ」と，ふりがな，辞書情報など を付与するための「読解補助情報エディタ」である。本稿では 2 つエディタを総称してやさ しい日本語のニュースの「制作支援システム」と呼ぶ.

NHK では制作支援システムのプロトタイプを 2012 年 4 月からの 1 年の公開実験期間中に利 用し，不具合の修正，改良を加えた。そして書き換え作業が安定し，改修すべき項目が明らか になった 2013 年 9 月に本運用システムの開発を始め, 2014 年 6 月に新システムに移行した。こ のとき読解補助情報エディタに自動学習機能を加えたことにより，6.3 節で詳述するように，制 作支援システム全体は日々のやさしい日本語のニュースの制作の中で自然と利便性が増すよう になった。

やさしい日本語を使った情報提供は急速な広がりを見せている4．ほとんどの事例は佐藤ら が公表している書き換え案文 5 や庵らの文法 (庵 2010, 2011) など，いわゆる書物の知見を使っ てほぼ人手で行われている。しかし今後やさしい日本語での情報提供を多様な人で効率的に進 めるには，技術的な支援が必須になっていくと考えられる．実際，NEWS WEB EASYの制作 フローを参考にしたやさしい日本語による自治体の情報提供のためのシステム開発が始まって いる (庵 2016). 本稿は類似した開発の参考になると考えている.

以下, 2 章ではやさしい日本語の書き換えの関連研究を概観し, 本研究の位置付けを示す． 3 章ではNEWS WEB EASYのサービス画面には, やさしい日本語のニュースのテキストとふり がななどの読解補助情報の 2 つの構成要素があることを述べる．4 章ではやさしい日本語の書 き換え原則を概説し，当初の原則には網羅性の低さの問題があったことを指摘する. 続く 5 章 では制作の体制およびプロセスを報告し，特に，やさしい日本語の書き換え原則の網羅性の低 さをカバーするため, NEWS WEB EASYの制作を記者と日本語教師の共同作業で実施する体 制を採ったことを述べる。さらに 6 章では開発した「書き換えエディ夕」と「読解補助情報エ ディタ」を説明する。書き換えエディタは, 記者と日本語教師の共同作業特有の問題, 書き換 え原則の不十分さに対処していることを述べる。また読解補助情報エデイタは，ふりがななど の読解補助情報を自動で推定し，これを修正した結果を自動学習する機能を持つことを説明す る. 続く 7 章では，制作に関わる記者および日本語教師全員に対して実施したアンケートと書 き換えエディタのログの分析を通じて 2 つのディタの効果を示す.

\footnotetext{
4 弘前大学の 2015 年 4 月の調査によると 47 都道府県すべてでやさしい日本語が活用されている. http://human.cc.hirosaki-u.ac.jp/kokugo/EJ1a.htm

5 脚注 4 参照.
} 


\section{2 関連研究}

やさしい日本語での情報提供にはさまざまなプロセスが必要だが, 本章ではその中心となるや さしい日本語への書き換えの関連研究, 特に最も関連が深い文書の平易化 (text simplification) の研究を概観する.

文書の平易化とは与えられた文書の基本的な意味は変えずに，文法的，語彙的な複雑さを減 らす操作であり (Siddharthan 2003) これまで英語を主な対象としてさまざまな研究が展開され ている (Shardlow 2014; Siddharthan 2014).

平易化の目的は大きく 2 つに分類できる，1つは自然言語処理システムの前処理に平易化を 入れることで全体の性能を向上させる研究である。平易化はさまざまな処理に応用されており, 構文解析 (Jonnalagadda, Tari, Hakenberg, Baral, and Gonzalez 2009; Chandrasekar, Doran, and Srinivas 1996), 関係抽出 (Miwa, Sætre, Miyao, and Tsujii 2010)，意味役割付与 (Vickrey and Koller 2008) などの例を挙げることができる.

他の 1 つは言語の理解力が十分でない人の情報アクセシビリティの改善を目的とした研究で ある。失語症の人 (英語) (Carroll, Minnen, Pearce, Canning, Devlin, and Tait 2009), 読み書 き能力が不十分な人（ブラジルポルトガル語） (Watanabe, Candido Jr., Uzêda, Fortes, Pardo, and Aluísio 2009), 知的障害のある人 (スペイン語) (Bott and Saggion 2012), 非母語話者（英 語）(Siddharthan 2002) などを対象とした研究が行われている.

平易化の手段に目を向けてみると，研究の初期は使える言語資源や技術が限られていたことか ら，経験則に基づいたルールで文書を変換する手法が主流であったが (Chandrasekar et al. 1996; Carroll et al. 2009; Siddharthan 2002), 近年 Simple English Wikipedia に代表されるやさしい言 語で書かれた大きな言語資源が使えるようになってきたこと, 単言語パラレルコーパスのアラ インメント技術が進んできたこと (Barzilay and Elhadad 2003; Nelken and Shieber 2006) から, パラレルコーパスからデータ主導で自動書き換えシステムを構築する研究が進展している. 例 えば, Coster and Kauchak (2011) は Wikipedia と Simple English Wikipedia を使ったパラレル コーパスを作成し，統計翻訳ツールキット， Mosesを使った統計的平易化システムを作成して いる.

次に，本稿と同じく日本語能力が十分でない人の情報アクセシビリティの改善を目的とした 平易化の研究に目を転ずると ${ }^{6}$ ，ろう者を対象とした語彙・構文書き換えシステム (Inui, Fujita, Takahashi, and Iida 2003), 子供や日本語学習者への利用を目指した語彙変換システム (梶原, 山本 2015) などがある。 また英語ほどではないが，近年パラレルコーパスが利用可能となった ことから統計機械翻訳技術を使ったやさしい日本語自動変換システムも報告されている (松田

6 特定の人を対象としない「言い換え (パラフレーズ)」分野にも関連研究が多数あるが, 紙幅の関係で割愛する. 
2010; Goto, Tanaka, and Kumano 2015; 熊野, 田中 2016).

以上で概観してきた研究は文書を自動的に平易化しょうとするものであるが，人手による平 易化作業を支援する研究もある．平易化の支援にも，自動平易化と同様に機械翻訳などの自然 言語処理の前処理による性能向上 (Mitamura and Nyberg 2001) と人の情報アクセシビリティの 改善を目的とした研究がある. 以下では著者らと同じアクセシビリティの改善を目的としたシ ステムを概観したい。これまで提案されているシステムは 2 つ基本機能を持つ.

(1) 文書中の難しい部分を指摘する機能

(2) その書き換え候補を提示する機能

例えば伊藤, 鹿嶋, 前田, 水野, 御園生, 米田, 佐藤 (2008) は外国人のためのやさしい日本 語文書の作成支援を目的とした書き換え支援システムを提案している．同システムには入力さ れた文書中の難しい語を指摘し，代わりに使える語を提案する機能が実装されている。難しい 語は形態素解析システムに事前に登録された難しい語彙を使って指摘し，やさしい語は，別途 収集したやさしい語彙と難しい語の類似度を使って提示する。さらに長文，および使うべきで ない文法的表現を指摘する機能を持っている.

ボーイング社は, 航空機の整備マニュアル用の Simplified English の基準に従った文書作成 を支援する語彙と文法のチェッカーを開発している (Hoard, Wojcik, and Holzhauser 1992). Simplified Englishの読者には英語非母語話者が想定されている。また，語彙には強い制限があ り，同じ概念に属する使える語と使えない語が辞書にまとめられている。チェッカーは辞書を 使って，難しい語を指摘して代替候補を提示する。

以上, 自動平易化, 平易化支援についての研究を外観してきたが, ここで本稿の特徵をまとめ たい、まず，本稿はNEWS WEB EASY というやさしい日本語のサービスを実現するためのよ り具体的, 包括的な報告となっている点に特徴がある。実際本稿では, 技術的な内容に先立ち, NEWS WEB EASY のためのやさしい日本語の特徵, Web で提供する全情報，および, NEWS WEB EASY の制作のために採用した体制と制作プロセスを説明し，制作支援システム構築の 課題を明らかにする。そして，課題を反映して開発した「書き換えエディタ」および「読解補 助情報エディ夕」を報告する。一方，上記一連の関連研究は，自動平易化，あるいは平易化支 援に関する個別の技術報告となっている。本稿のように具体的なサービスに関わった日本語の 平易化の支援技術の報告は著者らの知る限り初めてである.

次に本稿の 2 つのディタのうち書き換えエディタに着目する。書き換えエディタは平易化 作業の支援という点で伊藤 他 (2008), Hoard et al. (1992) と目的が同一であり，かつ前述の基 本機能 (1) および (2) に基づく点が共通している. しかし以下の 3 点に違いがある.

1 点目は書き換えエディタの難しい語を指摘する機能に学習機能が備わっている点である. 難 しい語の指摘には語の難易度を使っており，難易度推定機能で語の難易度を自動認定する，難 易度推定機能には学習機能があり，推定誤りを日々修正することで性能が自然に向上するよう 
になっている7.

2 点目は書き換え候補を直接提示しない代わりに，用例検索機能を持っている点である。す なわち書き換え候補は作業者が自動蓄積された書き換え元の記事とやさしい日本語の書き換え の用例を検索して自ら見い出すようになっている。用例検索を利用したのは著者らのやさしい 日本語の書き換え原則が当初不十分で，ニュースの難しい表現とやさしい代替表現を事前に準 備できなかったために採用した措置であるが，あらかじめ候補を用意する手法に比べると，運 用により自然に用例の蓄積が進み，さまざまな表現が検索可能になる特徴がある.

3 点目は複数作業者の書き換えを支援する共同作業支援システムになっている点である。ニュー スの書き換えにはニュース原稿の編集の知識, および外国人の日本語能力の知識が必須なため, 書き換え作業を日本語教師と，経験豊かな記者が共同で担当するようにした。そして 2 名の作 業を支援するため，書き換えエデイタは複数作業者の共同作業ができるようにした．さらに日 本語教師と記者の専門性が異なる点に配慮して, 共同作業が円滑に行える仕組みを提供した。

なお上述の 3 点の特徵は NEWS WEB EASY の固有の状況を反映させたために生じている点 を指摘しておく．詳細は次章以降に譲るが，固有の状況とは，当初の著者らの書き換え原則は 先行事例に比べて不十分であったこと，不十分さを補うため複数の専門家が共同作業する必要 があったこと, 網羅的な書き換え原則をあらかじめ用意することができず専門家が書き換えを 通じて発展させていく方針を採用したことである。本稿の書き換えエデイ夕は，先行研究が準 拠する上述の 2 つの基本機能に NEWS WEB EASY の固有の状況を満足するため, 学習, 類似 用例検索, 複数人での書き換え機能を組み合わせて統合したものと見ることができる.

\section{NEWS WEB EASY の概要}

本稿の制作支援システムで最終的に作成する NEWS WEB EASY のスクリーンショットを 図 1 に示す8. NEWS WEB EASY は, NHKの通常のニュースページである NEWS WEB に掲 載されたニュースをやさしい日本語に書き換えて作成する。画面の下部には情報の中心である やさしい日本語に書き換えたニュースが掲載されている.やさしい日本語のニュースは次章で 述べる書き換え原則に沿って作成するが，やさしく書き換えられず難しい表現が残ることがあ る。そこで難しい表現に対してはWebの機能を利用して読解を補助する情報を提供している. NEWS WEB EASY Web で提供しているのは読解補助情報を提供しやすいという利点がある ためであり(田中, 美野 2010), 具体的には以下を提供している.

・ふりがな

\footnotetext{
7 正確には 6.3 節で述べるように, 読解補助情報エディタの学習機能を利用しており, 修正も読解補助情報エディタ で実施する．学習結果は書き換えエディタに自動的に反映される。

8 脚注 3 の URL 参照.
} 


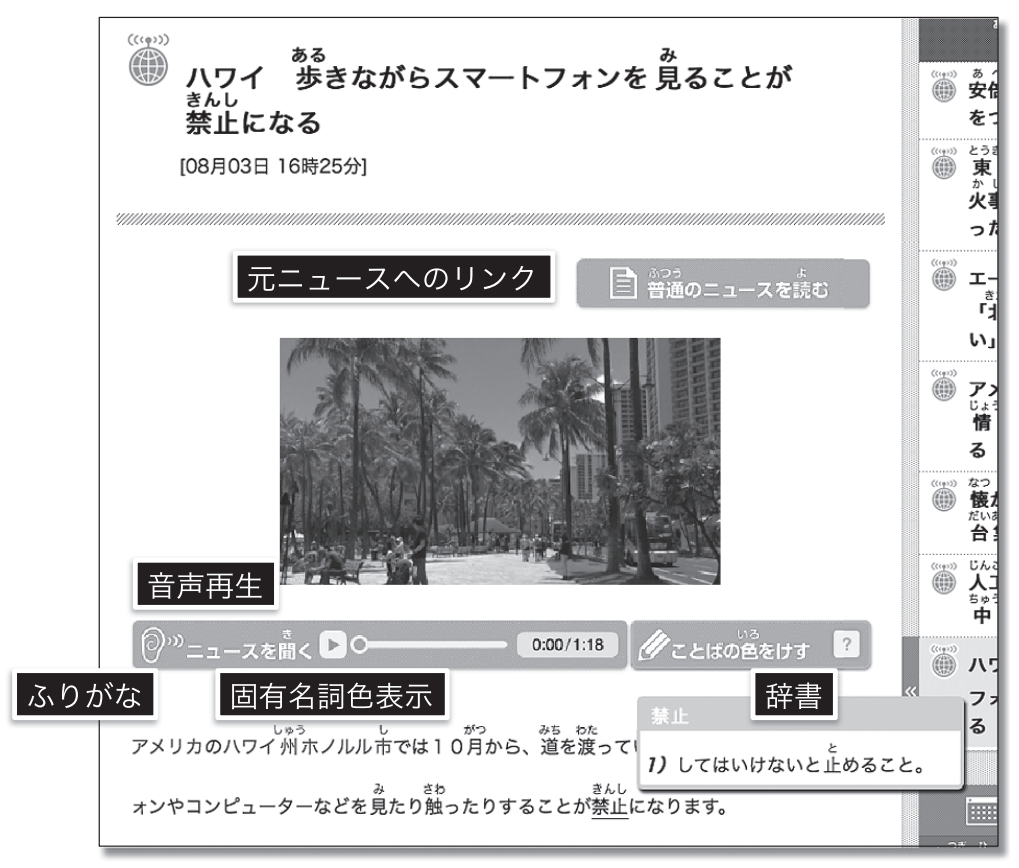

図 1 NEWS WEB EASY の画面

漢字を読むことは外国人にとって特に難しい。そこで，すべての漢字にはふりがなを付 けている。

- 辞書

すべての語をやさしくできるとは限らないため, 難しい語に辞書の説明を表示するよう にした．原則として 2 級以上の難しい語にカーソルを合わせると小学生用の辞書 (田近 2011)の説明が現れる.

- 語の色分け

ニュースには地名, 人名, 組織名などの固有名詞が頻繁に現れる. 固有名詞は辞書にほ とんど収録されておらず，数が多いので説明を付ける労力は大きい。そこで，固有名詞 をあらかじめ決めた色, 地名を紫, 人名をピンク, 組織名を空色で表示し, 意味が具体 的に分からなくても，色によって地名，人名，組織名の判別ができるようにした．

以上の読解補助情報に加えて，下記の追加情報も提供している.

- 合成音声

読むのが苦手でも聞くのは得意な外国人のため, 合成音声による原稿読み上げ機能を付 加している.

- 元のニュースへのリンク 
やさしい日本語のニュースには, 元のニュースへのリンクを付与しており, リンクを通じ てやさしい日本語を読解補助として，元のニュースを読むことが可能である，また，や さしい日本語で削除された情報を元ニュースで確認することも可能である.

著者らの目的は以上で説明した NEWS WEB EASY の画面の制作であり，実施には，やさし い日本語への書き換え原則，書き換え作業の体制とプロセス，制作作業の支援の 3 項目の検討 が必要となった，以下， 3 項目の内容を報告する。

\section{4 ニュースのためのやさしい日本語}

本章では NEWS WEB EASYで利用しているニュースの書き換え原則の概要を説明する，ど のような言語にも汎用的な制限言語は存在しないと言われているように (Mitamura and Nyberg 2001), すべての分野に共通するやさしい日本語の書き換え原則というのは存在しない. ニュー スのための書き換え原則は自ら作成する必要があった．しかし書き換え原則をゼロから作るの は膨大な作業となるため, 先行研究である「減災のためのやさしい日本語」(佐藤 2004)の原則 を修正，拡張するという手順に従った，減災のためのやさしい日本語は，災害発生から 72 時間 以内に自治体, 公共機関などから発信される情報が主な対象であり, 日本語能力試験の 3 級と 4 級の語彙と文法の範囲で書くことを原則としている.

日本語能力試験は学習者が受験する試験であり, 日本語能力を入門レベルの 4 級から最上級 の 1 級までの 4 段階で認定する ${ }^{9}$. また試験の出題基準 (国際交流基金，日本国際教育協会 2007) には各級の出題の目安となる語彙や文法事項のリストが公開されている.

減災のためのやさしい日本語の対象とする災害情報は, 著者らの対象の一般のニュースと, 話題, 文体, 文書の長さなどさまざまな要素が異なるため書き換え原則を修正する必要がある. そこで減災のためのやさしい日本語の原則に従ってニュースを実験的に書き換え, 原則の不足 やニュースとの不整合を拡張, 修正することにした，書き換え作業は出題基準に精通している 日本語教師 2 名が担当し, 検討は書き換えを担当した日本語教師, 記者 $\mathrm{OB}$, 記者, 著者らで実 施した (田中, 美野 2010). 以下では, 本稿に直接関わる語彙, 文法, 内容の削除と追加に関わ る書き換え原則の基本部分を説明する，詳細は (田中，美野 2016)を参照されたい.

\section{1 語彙}

日本語能力試験の出題基準の 3 級と 4 級には合わせて約 1,600 語が記載されており, 基本的 にはこの 1,600 語の範囲でニュースを書き換えるようにした。 しかし 1,600 語の多くは日常生 活で使われる語であり, 事件, 事故, 政治, 経済, 科学, スポーツ, 気象などの分野が中心と

${ }^{9} 2010$ 年に新試験が始まり, レベルは入門の N5 から最上級の N1 までの 5 段階に変更された. 
なるニュースの語はかなり不足している，例えば，「接待，公共事業，補正予算案，お内裏様」 などの語は書き換え実験で出てきたが 1,600 語には入っていない. 1,600 語に入らない難しい語 に対応するやさしい語があれば置き換えられるが，必ずしもあるとは限らない．また対応する やさしい語のない難しい語を無理にやさしく書き換えると不自然な日本語になるため，書き換 えずに辞書などの読解補助機能を使うことにした.

\section{2 文法}

- 文の長さ

文が長くなると文意が分かりにくくなりやすいため，文書作成の参考書では短文を勧め ている。ニュースのやさしい日本語でもこの原則に従い，1文をできるだけ50 文字以下 に書き換えるようにした。ニュースは 1 文が長くなる傾向があり，短文化の作業は多く 発生する。

- 受動態

受動態は日本語能力試験の 3 級に分類される文法であり学習の時期は早い. 一方, 意味 が間接的になるので，多くの文章作成の参考書では能動態を使って直接的に書くことを 勧めている，特に，日本語の場合には受動態の「れる・られる」が可能，自発，尊敬の 意味でも使われるので，外国人が混乱する恐れがある，以上の要因を考慮して，二ュー スのやさしい日本語では受動態をできるだけ能動態に書き換えることにした.

- 慣用表現

ニュースには「〜としています, 〜と見られています」や「この事件は〜したものです」 (田中 2012) などの独特の慣用表現が多く出てくるが, 日常会話にはほとんど出てこない. 外国人にとっての慣用表現の難易度は高いと考え，普通の表現に書き換えることを原則 とした.

\section{3 内容の削除と追加}

長いニュースは読者の負担になるため，次のような内容を削除して整理する.

- 重複の削除

ニュースには通常，冒頭のリードと本文がある。リードはニュースの要約であり，本文 の一部を抜粋して作るため本文と重複する。重複はリードから，もしくは本文から削除 することを原則とした。

- 周辺的な情報の削除

内容理解に必須でない背景, 関連情報の文や段落を削除する.

一方，情報を追加する場合もある．特に専門用語などで対応するやさしい日本語がない場合説 明を追加する，例えば実際のニュースでは「タブレット端末」に対して「（＝薄い板のようなコ 
ンピューター)」という説明を直後に追加している。

\section{4 ニュースの書き換え原則の課題}

初期のニュースの書き換え原則には「不十分さ」の問題があったことを注意をしておきたい. 制限言語の研究分野では言語の制限の仕方を 2 つに分類することがある (Mitamura and Nyberg 2001; Kuhn 2014). 1つは使うべき語彙と文法を規定する規範的なアプローチ (prescriptive approach)で, 他の 1 つは使ってはいけない語彙と文法を規定する禁止的なアプローチ (proscriptive approach) である。この分類で上述の原則を見ると, 当初は日本語能力試験の 3 級と 4 級の語 彙と文法を使うという規範的な原則が支配的で, 受動態を使わないという禁止的な原則が多少 入っている状態であった，日本語能力試験の 3,4 級レベルは日常会話が対象であるため，規範 的，禁止的原則のいずれもニュースを記述するには「不十分」であった。

実際，NHKのニュースには明文化されていない規範的原則と禁止的原則がある．例えば，人 が亡くなっているように見えても脳死が判定される前は「心肺停止の状態」という表現を使わ なければならないという規範的原則, 推量を表す「らしい」は主観が強く反映されるので使わな いという禁止的原則などである。ニュースをやさしく書き換えるには，日本語教育とニュース の規範的，禁止的原則を整合させた原則が必要だが10, サービスの開始時までにニュースの表 現を網羅的に検討することはできず，当初の書き換え原則にはニュースの観点が不足していた.

著者らのニュースの書き換えに対して, Hoard et al. (1992)の航空機マニュアルの書き換えは 相当に「十分」な原則の元で行われる. また Mitamura and Nyberg (2001)の機械翻訳用の書き 換えも著者らより多くの原則を設定していると思われる。書き換え原則の不十分さは著者らの 問題の特徵と考える。なお，以後本稿では特に断らない場合，禁止的原則と規範的原則の両方 を合わせて原則と呼ぶ.

\section{5 体制と制作プロセス}

やさしい日本語のニュースの公開を 2012 年 4 月に開始した. 土・日と祝日を除いて月曜から 金曜まで毎日，一般向けのニュースをやさしい日本語に書き換えて提供している. 最初は平日 1 日 1 記事から 2 記事を公開していたが, 作業手順の見直しなどを経て， 2013 年 6 月からは 1 日 5 記事を公開するようになっている。以下現状の制作の体制とプロセスを説明する。

\section{1 体制}

書き換え原則に沿ってニュースをやさしい日本語の書き換える場合，4.4 節で述べたように， 当初は書き換え原則が不十分だったため, 日本語教育とニュースの両方の知識を持つ人が必要

\footnotetext{
10 実験的な書き換えを通じてニュースらしさをある程度保持すべきという結論になり，両方の原則を考慮することに なった。
} 
となった. しかし，両方の知識を持つ人はいなかったため, 日本語教師と記者の両者が相談し ながら書き換えを進める体制を採用し，現在に至っている，日本語教師と記者のほか，書き換 え内容を最終的に確認する編集責任者 ${ }^{11}$ おび，合成音声の付与作業を行う技術スタッフも参 加する。なお特にサービス開始からしばらくは，すべての書き換えを元記事を書いた部局に確 認してもらっていたが, 現在は編集責任者の判断で必要に応じて確認を依頼するようになって いる.

\section{2 制作プロセス}

現在 NEWS WEB EASY では原則, 午前中に 2 記事, 午後に 3 記事の 1 日 5 記事を公開して いる．午前中公開の 2 記事は前日に作成し，午後公開の 3 記事は当日作成する。 えは日本語教師 2 名, 記者 1 名, および編集責任者 1 名が担当する. 最終的な 5 記事の確認は 編集責任者が担当する。編集責任者は内容の確認だけでなく，日本語教師との書き換え作業も 一部担当している。以下，制作の流れを記す。

(1) 記事選択

一般向けのニュースサイト NHK NEWS WEB に当日までに掲載されたニュースから，大 きな話題，外国人や子供 ${ }^{2}$ に適すると思われる話題を持つものが選ばれる．同一話題の ニュースを継続して提供できるとは限らないため, 節目や一話で完結している記事が選 ばれる，選ばれた記事を元記事と呼ぶ。記事の選択は編集責任者が行う.

(2) 引き継ぎ事項の確認

日本語教師は日々の書き換えで難しかった点などを日誌, メールで情報共有しており前 日の内容を確認する.

(3) 背景情報のリサーチ

日本語教師を中心に，関連ニュース，関連サイト，報道発表などの関連情報をリサーチ する。用例検索機能で過去の類似記事も検索し検討する.

(4) やさしい日本語への書き換え

主に日本語教師が表現をやさしくし, 記者が元記事の再構成, 要約, 内容の確認を行う. 書き換えが終わると編集責任者の確認を受ける。さらに元記事を書いた出稿部に確認を 依頼することもあり, 出稿部から質問や修正の依頼があれば検討し, 必要に応じて修正 する．このプロセス全体で 1 記事およそ 2 時間の作業である.

(5) 読解補助情報の付与

やさしい日本語のテキストが完成した後，漢字のふりがな，難語への辞書の説明，固有 名詞のカラー表示といった読解補助情報を付与する. 付与作業は日本語教師が担当する.

\footnotetext{
11 編集責任者も記者である.

12 NEWS WEB EASY では外国人に加えて小・中学生も対象としている.
} 
現在は 1 記事およそ 10 分の作業である.

(6) 合成音付与と試写

やさしい日本語のテキストの合成音を付加して必要に応じてイントネーションの調整を 行う。最終的な画面が完成すれば試写を行い問題なければ公開する.

（7）日誌，メールの作成

日本語教師は書き換えの問題点，気づいた点などを業務日誌に記載し，メールでも情報 を共有する。

上記の仕事のうち，(4) やさしい日本語への書き換え，および (5) 読解補助情報の付与には手 間と時間を要するため, それぞれを支援する「書き換えエディタ」と「読解補助情報エディタ」 の開発を進めた。

\section{6 制作支援システム}

本章では専門性の異なる日本語教師と記者の共同書き換えを支援するために開発した「書き 換えエディタ」と日本語教師の読解補助情報付与作業を支援するために開発した「読解補助情 報エディタ」について説明する。

\section{1 書き換えエディタ}

\subsection{1 日本語教師と記者の書き換えの課題}

サービス開始前に日本語教師と記者でニュースを実験的に書き換えたところ 2 つ課題があ ることが分かった１つは表現が迷走したり，極端な場合には書き換えが中座したりする「書 き換えの停滞」の問題である.

ニュースをやさしい日本語に書き換えるには 4.4 節で述べた記者の専門であるニュースと，日 本語教師の専門である日本語教育に由来する 2 つの書き換え原則に熟知している必要がある. 一方, 初期の日本語教師と記者は互いに相手の知識が不足していたため, 記者の表現の書き換 えが外国人にとっては難しかったり，日本語教師が行った省略がニュースの重要箇所であった りという問題が何度も発生し，書き換えの停滞が発生していた。 なお停滞は，実験時には書き 換えに非常に長い時間がかかる結果となるが, サービス時には時間が限られているため, 満足 できない書き換えで我慢する結果となる。

他の 1 つは元記事が十分平易化されない問題である. 大きな要因に書き換えの着目点の見過 ごし，すなわち難しい語や長文の見過ごしがあった．書き換えの着目点が日本語教師と記者の 組み合わせによらず，また日々一定していれば，原則に従った平易化レベルの安定した実現に つながる，本稿では人によらず一定レベル以上の平易化を達成することを「平易化レベルの保 証」と呼ぶ. 特に初期には書き換え原則を記憶しておくことが難しいため平易化レベルの保証 が難しかった。 


\subsection{2 解決方針と実装した機能}

書き換えの停滞を軽減し平易化レベルを保証するため次の方針を立てた.

- 方針

- 書き換えの役割分担による運用

記者と日本語教師のそれぞれの専門知識に応じた平易化を担当するよう以下のよ うに役割を分担した。

* 記者

文の順番の入れ替えなどによる記事の再構成で平易化する，不要な部分を 要約する，文を分割して不要な成分を省略する，日本語教師の書き換え結 果を承認する。ただし表現の平易化は行わない.

* 日本語教師

難しい語や表現を平易化する。文の分割は行うが省略は行わない.

- 書き換えエディタによる難しい語と長文の指摘

ニュースのやさしい日本語の書き換え原則に従って難しい語と長文を指摘する. 難しい語や長文の見落としが減り，作業者によらず平易化レベルを一定以上に保 つ効果が期待できる。また，日本語教師と記者で書き換えを相談するときに指針 として利用できる。

- 書き換えエディタによる書き換え候補の提示

多様な書き換え候補の提示で停滞の軽減が期待できる。またニュースに必要な表 現の統一にもつながる.

以上の方針を実現するよう書き換えエディタに下記の基本機能を実装した.

・書き換えエディ夕の基本機能

- 難しい語と長文の指摘

日本語能力試験に登録されて入る 1 級から 4 級までの語彙を形態素解析システ ム 13 のシステム辞書に登録し，それぞれ色分けして表示するようにした。 4.1 節で 述べたように, 日本語能力試験出題基準の 3 級と 4 級の語彙を基本的に使うため, 日本出題基準に登録されていない語 (未知語)，1 級および 2 級の語が書き換え候補 となる。また，長文への注意を喚起するため 1 文の文字数を表示するようにした.

- 書き換え候補の提示

難しい語は日本語能力試験の出題基準のリストで決定できるが, 難しい語の書き 換え候補をすべて事前に準備することは容易ではない，また，出題基準のリス卜 がすべての語彙をカバーしているとは限らないという書き換え原則の不十分さへ

$13 \mathrm{MeCab}$, IPA 辞書使用. 
の対応が必要である．以上に対処するには，日々の元記事と書き換え後の記事を データベースに自動的に登録し，表現を検索する手法が有効と考え「用例検索機 能」を提供することにした。元記事の難しい表現の書き換え例を知りたい場合， 用例検索機能に難しい表現を入力し, 記事, もしくは文と共に提示されたやさし い書き換え例を参照する，用例検索機能には語，フレーズ，文など任意の長さの 表現を入力することができる，そして入力表現中の内容語の数，および内容語間 の間隔を使って類似表現が元記事のデータベースで検索される．検索された難し い表現と, 対応するやさしい日本語の表現は, あらかじめ対応付けされてデータ ベースに格納されている記事，もしくは文の単位で表示される。本機能はすでに 多言語翻訳の現場で利用実績のあった翻訳用例提示システム (熊野, 後藤, 田中, 浦谷, 江原 2001) を流用して実装した。

以上は難しい表現を指摘してその書き換え候補を提供する基本部分である。これに日本語教師 と記者の共同作業のために以下の機能を設けた.

・共同作業のための書き換えエディタの機能

- 複数作業者の利用

ユーザとして登録された人は誰でも書き換え作業に参加できるようにし，任意の 順番で 1 つの記事を書き換えることを可能とした。基本は記者と日本語教師の交 互の書き換えである.

- フラグ付き書き換え原稿の履歴保持

書き換えた原稿には記者や日本語教師といった「作業者属性」あるいは確認用な どの「目的属性」を表すフラグを付与し履歴を保存するようにした．作業者属性 と目的属性を明示することで，日本語教師は表現の書き換え，記者は内容の書き 換えという役割を分離しやすくなる．また書き換えの履歴によって変更の詳細な 経過を確認できる。

- 原稿難易度スコアの表示

記者と日本語教師の書き換えがやさしくなる方向に進んでいるかどうかを確認する ために原稿難易度スコアを提示するようにした，原稿難易度スコア $S$ は文書リー ダビリティの研究で用いられている属性 (野本 2016) を参考に「文書長 $d\rfloor$, 「平均 文長 $l 」$, 「難語率 $\left.w^{14}\right\rfloor$ の積 $S=d l w$ で計算した，右辺の各項は小さいほどやさし いので, 積の $S$ は小さいほど原稿がやさしいことを示す。原稿のやさしさは書き 換えエデイ夕の画面に表示された個別の文長, 語の色表示でもある程度把握でき るが，1つのスコアにまとめることでより明確になる。さらに難易度スコアは専

14 文書中の語彙数に対する級外語彙, 1 級, 2 級の語彙数の割合. 
門性の違う 2 人が書き換えを検討するときの指針としても有用と考えた.

- コメント機能

専門性の違う作業者を支援するにはコミュニーケーションを支援するのが有効と 考えた。直接会話できれば問題ないが, 書き換えエデイタは日本語教師, 記者など が遠隔地で作業することも想定してWebのシステムとして実装した。このため， 直接会話できない場合，作業時間がずれる場合もあると考え，文単位でコメント を残せるようにした。コメント欄には書き換えの意図，質問などを記入する.

\subsection{3書き換えエディタの機能の補足}

前項の機能に関して下記 2 点を補足しておきたい.

- 難しい語の指摘

日本語能力試験の級の認定は，難しい語の指摘，原稿の難易度スコアの計算に使われる ため正確に実施したい，級の認定は形態素解析に基づいているため，その誤りの手軽な 修正インターフェース，および学習機能を導入して自律的に性能を向上させる機構の必 要性は明白だったが，サービス開始までに対応することができず， 6.2 節で説明するよう に後に対応することとなった。

- 用例検索機能の意義

やさしい日本語の書き換え原則は 4.4 節で述べたようにNEWS WEB EASY の開始時に は日本語教育のみを反映した「不十分」なものであった。しかしこの原則の不足を補い ながら日々日本語教師と記者が日々作成する書き換えには，規則の形で明示されてはい ないが，さまざなニュースの書き換え原則も反映されているはずである。すなわち書き 換えを蓄積して再利用することは，実質的に原則の開発を書き換え作業者に任せること を意味する。著者らはニュースの書き換え原則は作業者の高い専門性を頼りに用例検索 システムを使って自律的に発展させるのが現実的だと考える。ただし一般に実用されて いる制限言語を見ると，言語仕様の開発や管理は作業者とは別の人，団体に任せること が普通のようである ${ }^{15}$ 。このような場合に単純に用例検索システムを導入するのは不適 切と考える。

\subsection{4 書き換えエディタの画面}

書き換えエデイタの主な機能を画面で説明する．図 2 にメイン画面を示す，メイン画面の上 部は原稿の書き換え履歴, 下部は書き換え作業の画面である。メイン画面からは後に説明する 3 原稿比較画面 (図 3), 原稿差分画面, 文の重複画面, 単一原稿画面を表示させることができる.

15 例えば Hoard et al. (1992) の航空機マニュアルの言語仕様は AECMA という団体が管理している.また企業情報 の開示文書作成のための Plain Engish は米国証券取引委員会が管理している. 


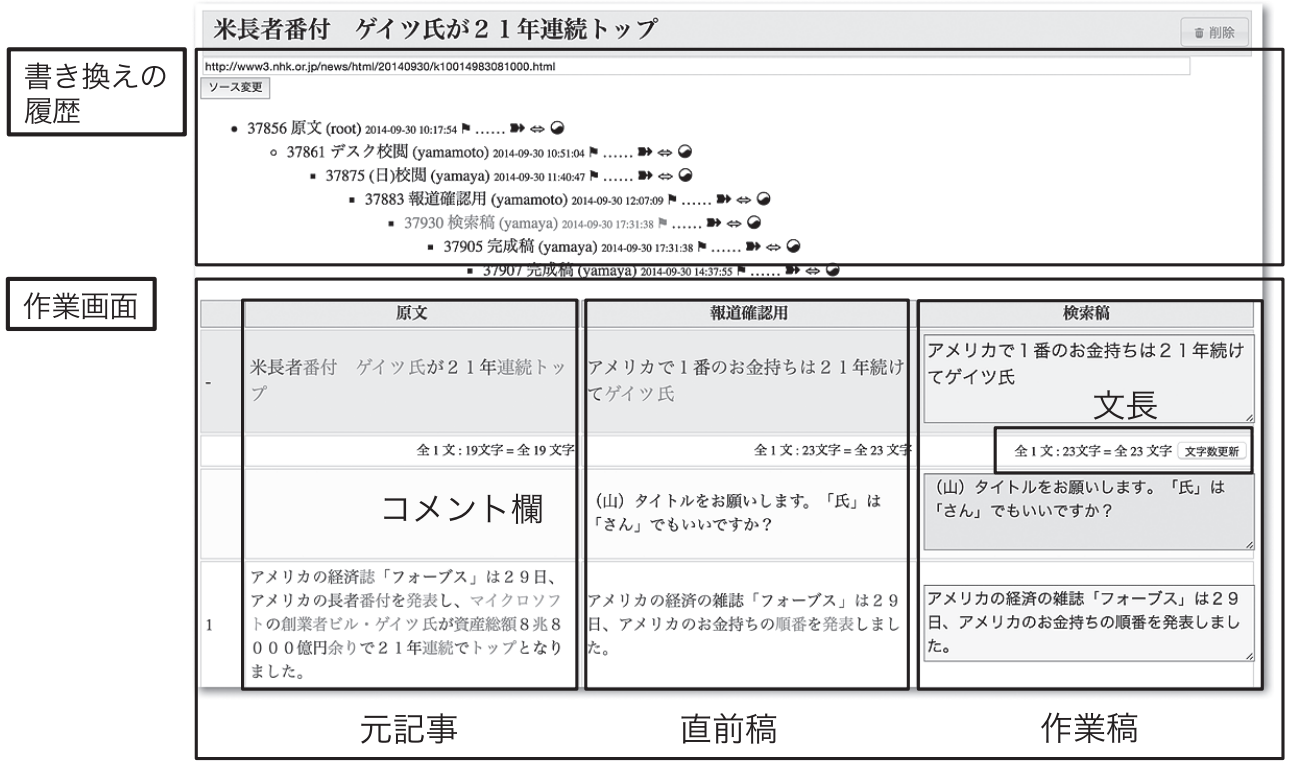

図 2 書き換えエディタのメイン画面

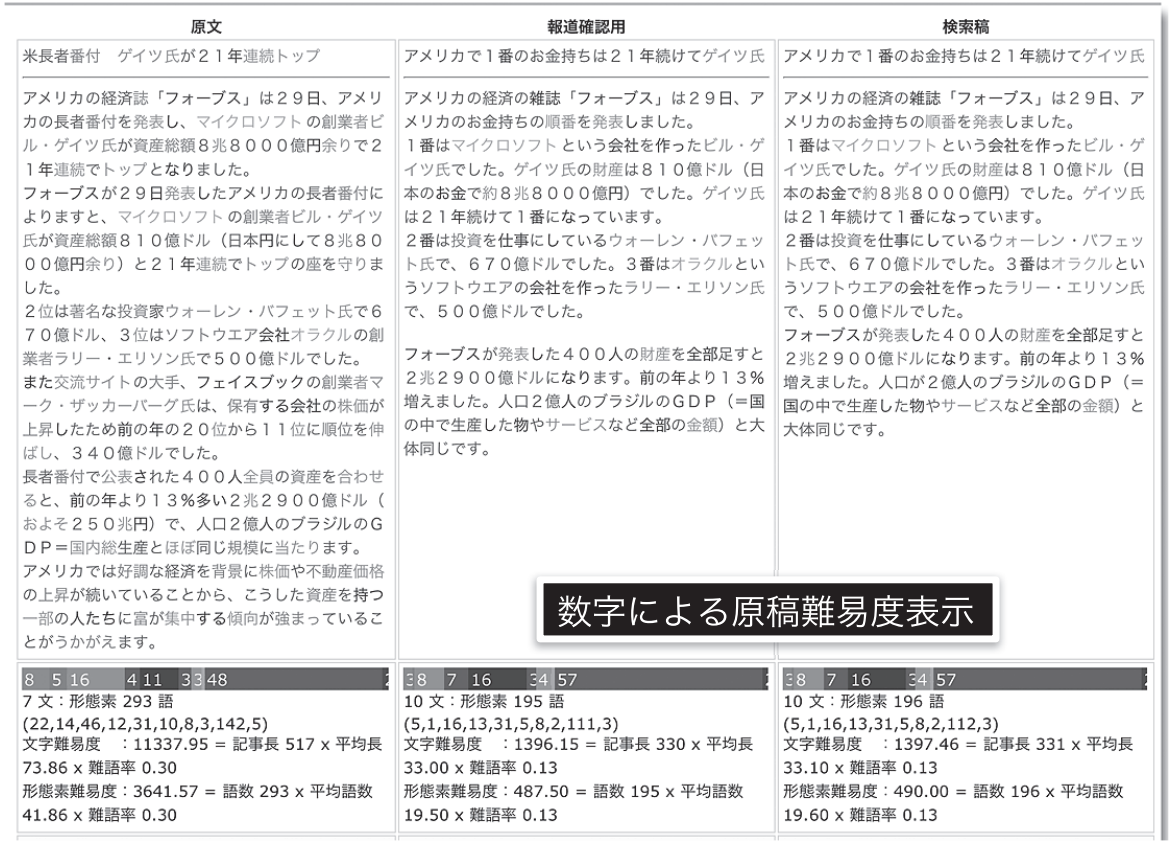

図 3 書き換えエディタの 3 原稿比較画面 
(1) 書き換えの履歴

図 2 の上段が元記事の書き換え原稿の履歴である。書き換え作業者はまず元記事のコピー を作成し最初の書き換えを作成する，次の作業者はそのコピーを作成し，さらに平易化 する。ささらにその後もコピーと平易化を繰り返し，作成される書き換え原稿すべてが履 歴として記録される。書き換えの記録には木構造を採用しており，線状に並ぶ履歴だけ でなく，兄弟ノードを作ることで複数系統の履歴を作ることができる．図 2 の履歴部分 には「原文 (本稿の元記事)，デスク校閲（本稿の記者の書き換え），（日）校閲（本稿の 日本語教師の書き換え), 報道確認用 (本稿の編集責任者確認用), 検索稿 (本稿の検索 機能への入力用) ・・・」といったフラグのついた書き換え原稿が並んでいる.

(2) 作業画面

- 記事編集と登録

書き換えの履歴の下が作業画面である。枠で囲んだ 3 列の左端は元記事，中央は 直前稿，右端が作業稿，すなわち現在の書き換えである．表示される原稿の関係 は常に同じである。それぞれの列には，文編集用の箱とコメント用の箱のペアが 下方向に繰り返し表示される。図 2 ではタイトル, タイトルヘのコメント，書き 換え稿の 1 行目の 3 つの箱が表示されている. 左端（元記事）と中央の列（直前 稿）は閲覧のみ可能で，右端（作業稿）の文編集用の箱とコメント用の箱は編集可 能となっており, 最初は直前稿の対応部分がコピーされている. 作業者はコピー を書き換え，完了したら登録する。

- 文単位の書き換え

作業画面を横方向に見ると 3 つ箱が並んでいる．上で述べた文編集用の箱とコ メント用の箱で，元記事の 1 文単位に設けられ，横に整列して表示される．作業 者は右端の文編集用の箱の中で文の分割や書き換えを行う。文編集用の箱とコメ ント用の箱の数は元記事の文数に固定されており，右方向に見ることで元記事の 文の変化を観察できる，以上の元記事の文を基準に書き換えを表示する方式を箱 表示と呼ぶ.

- 文長の表示

文編集用の箱の直下に文長を表示している。目標が 50 文字程度以下であるため, 40 文字を超えて 60 文字までは青で，60 文字を超えて 80 文字までは黄色で， 80 文 字を超えると赤で文長を表示するようにしている.

・ コメント欄

コメント欄には文の書き換えに対するさまざまなコメントを記入する.

- 語の難易度表示

直前稿と元記事の文編集用の箱の中の語はカラーで表示される。色は日本語能力 
試験の級に対応しており，4 級を青， 3 級を緑， 2 級を黄色，1 級を暗い赤，級外 の難語を明るい赤とした，作業者は黄色や赤の語に注意して作業する.

- 3 原稿比較画面

図 2 の作業画面に対応する 3 つの画面を並べて表示することができる（図 3). メ イン画面にはコメントや文長情報があり一覧性が悪いが, 図 3 では全体を把握で きる，元記事，直前稿，作業稿と進むにつれ，青色，緑色の語の割合が増え，書き 換え稿の長さが短くなっていれば書き換えはやさしくなっていることになる。ま た, やさしさを数值で確認するため下段には原稿難易度スコアを表示している ${ }^{16}$.

- その他

書き換えが進むと直前稿との差がほとんどなくなるため, 書き換え原稿間の差分 文字列をカラーで強調表示する画面（原稿差分画面），要約作業を支援するため， リード文と他の文の一致文字列をカラー表示する画面（文の重複画面）を用意し た. また履歴中の任意の 1 つの書き換え原稿を色付きで表示することもできる（単 一原稿画面).

\section{2 読解補助情報エディタ}

書き換え作業が完了したやさしい日本語のテキストに対して以下の読解補助情報を付与する.

- ふりがな

すべての漢字に付与する

- 固有名詞の色表示

地名，人名，組織名に色をつける

- 辞書の説明

日本語能力試験の 2 級, 1 級, それ以上の難語に原則付与する。ただし, 辞書に適切な語 釈がない場合は付与しない

本節では上記の付与作業を支援する読解補助情報付与エディタを説明する。ふりがな，固有名 詞は既存の形態素解析システムで付与できる。また，日本語能力試験の級も形態素解析辞書の 語に 1 級から 4 級までの級を記載しておけば認定できる。また解析時に未知語を難語とするこ とで，1，2 級の難語とそれ以上の難語を自動認定できる。そこで当初は形態素解析器を応用し た読解補助情報付与システムを使用していた。しかし形態素解析を誤れば，ふりがな，固有名 詞，級の認定も誤ることになる。語の辞書引きには，形態素解析で得られる基本形の表記と読

16 ここでは原稿長と文長を文字列で測った場合と形態素数で測った場合の 2 種類の数字が並んでいる。それぞれ文字 難易度, 形態素難易度と表示されている。なお，例えば元記事の文字難易度の表示が $11337.95=517 \times 73.86 \times 0.30$ と等式になっているが，実際は難語率の表示を 3 桁に制限した $(0.30)$ ことによる丸め誤差で等式が成立していな い. 他の等式も同様である. 
みを使うため，辞書引きも解析誤りに影響される。また，辞書引きができても語釈が語の説明 としてふさわしくないこともある。さらに、ニュースには固有名詞, 複合名詞を中心とした新 語が頻繁に出現するため, 1 語へのまとめ, 属性の付与などが必要となる.

運用開始時はプロトタイピングと割り切り, 形態素解析システムを応用していたため誤りを 日々人手で修正する必要があった。しかし修正はその場限りでその後に反映されない。そこで, ふりがな，固有名詞の属性，表示する辞書項目，および語の日本語能力試験の級を予測し，か つ予測誤りの人手修正結果をオンライン学習できる「難易度, 補助情報付与モジュール」を作 成した。 さらに，予測結果を簡便に修正できるインターフェースを開発した。 以上により読解 補助情報の自動付与結果の誤りをインターフェースで修正すれば以後の解析に反映できるよう になった(熊野, 田中 2014).

難易度, 補助情報付与モジュールは（ふりがな, 日本語能力試験の級もしくは固有名詞の属 性, 辞書項目) という 3 つ組の夕グがついた形態素列をデータとして, 学習時にはデータを最適 分割して記憶する。学習は 1 記事ごとに行うので, 修正結果は直ちに学習される。さらに忘却 の機能を持つため, 例えば固有名詞の認定の方針が変わった場合などにも自動的に対応できる.

図 4 に読解補助情報エディタのインターフェースを示す。左が全体画面で, 右は全体画面か ら呼び出された辞書項目の検索画面である。作業者は全体画面に表示されている解析結果を見 て, 必要に応じて語の単位の変更, 級の修正, 辞書項目の変更などを行う。なお, 全体画面を 開いたときにはすでにその時点までの学習結果が反映されていることに注意されたい.

全体画面の右側は，左側の作業内容を確認する全体表示である。NEWS WEB EASYの画面 と同様の形式で漢字のふりがなが表示され，書き換えエディタと同様の形式で語の級，固有名

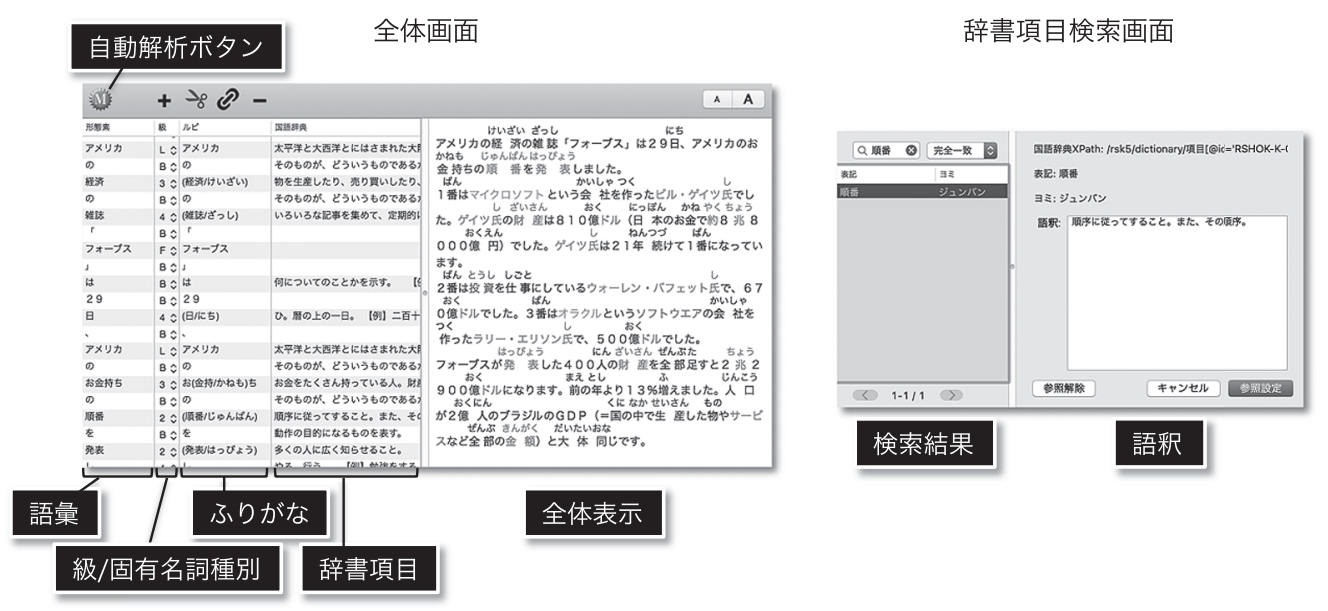

図 4 読解補助情報エディタ 
詞の種別が色分け表示されており，作業者は直感的に内容を確認することができる.

学習の効果に関して, 熊野, 田中 (2014) は 1,372 記事の各記事を対象にオンライン学習する 場合の解析精度と, 形態素解析システムを使った従来の解析精度を比較し, 形態素解析システ ムを使った精度は一定して $89 \%$ 程度であるのに対して, オンライン学習する手法では 250 記事 程度を学習すると約 $95 \%$ に達して飽和したことを報告している.

\section{3 制作支援システムのまとめ}

原稿と書き換えエディタ，読解補助情報エデイタ，用例検索の関係を図 5 に示す。管理シス テムとは原稿と各システムを制御するシステムである。図 5 では元記事が管理システムに登録 された後, 書き換えエディタにコピーされて，第 0 版から第 $n$ 版まで書き換えらえる状態を示 している。ささらに第 $n$ 版は読解補助情報エデイタに入力されて補助情報が付加される.

罒に示したように書き換え作業中には, 用例検索と, 難易度, 補助情報付与モジュールの語の 難易度推定機能が利用される。書き換え終了時には元記事（図中では書換 0 ）と第 $n$ 版の書き換 え（図中では書換 $n$ ）が用例検索システムに登録され，日々の運用で自然に用例が蓄積される. 読解補助情報の付与作業中は難易度, 補助情報付与モジュールのさまざまな情報推定機能が 利用される。そして誤りを訂正した結果が同システムに登録されて学習される.

すなわち，書き換えエディタ，読解補助情報エディタはそれぞれ日々の運用によって情報が フィードバックされ性能が向上する循環型のシステムになっている.

書き換え

読解補助情報付与

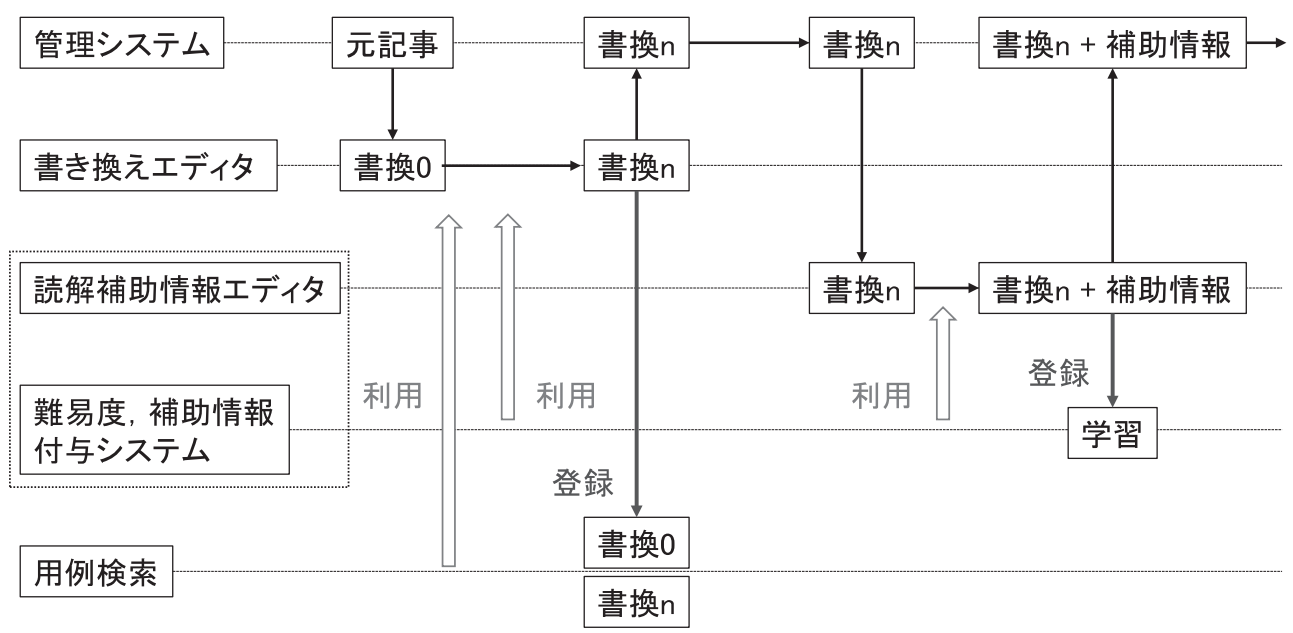

図 5 書き換え原稿の流れとシステムの関係 


\section{7 書き換え支援システムの効果}

本章では 2 つのエディタの効果を確認するために実施した調査を報告する．NEWS WEB EASY は実際のサービスであるため, エディタの利用・非利用の比較に基づく対照実験は困難 である。そこで，まず制作に関わっている日本語教師と記者全員に対するアンケート，さらに， システムに記録されているログの分析により効果を調査した.

\section{1 アンケート}

現在, NEWS WEB EASY の書き換えを担当しているのは表 1 に示す J1 から J4 までの日本 語教師 4 名, およびR1 から R3 までの記者 3 名である。 日本語教師 2 名および記者 2 名は 2012 年 4 月のサービス開始時から制作に参加している。日本語教師は 15 年以上の豊富な教育経験を 持ち, 記者はニュース原稿の作成の豊富な経験を有する OBであり, それぞれ高い専門知識を 持っている。今回のアンケートではまず文書で尋ね, 回答中の興味深い点, 疑問点をメールで 再度聞き取る方法を採用した。

\subsection{1 システムの全体について}

システム全体としての利点と問題点を把握するため下記の質問に自由記述で回答してもらっ た。質問趣旨と主な回答は以下の通りである.

(1) もし書き換えエディタのさまざまな機能および用例検索機能が現在使えないとすると品 質, 書き換え時間にどのような影響があるでしょうか.

- 作業時間は大幅に増え 1 日 3 記事担当するのは負担が大きそうである（他類似回 答 4 件).

・ システムを使わない場合, 異なる作業者間, 過去記事との間に大きな違いが出る と思う。一定の基準, レベルでの書き換えを保つためには必要だと思う（他類似 回答 4 件).

表 1 回答者の属性（調査当時）

\begin{tabular}{ccc}
\hline 回答者 & 制作参加時期 & 日本語教育年数 \\
\hline $\mathrm{J} 1$ & 2012 年 4 月 & 20 年 \\
$\mathrm{J} 2$ & 2012 年 4 月 & 15 年 \\
$\mathrm{J} 3$ & 2013 年 3 月 & 17 年 \\
$\mathrm{J} 4$ & 2015 年 3 月 & 15 年 \\
$\mathrm{R} 1$ & 2012 年 4 月 & - \\
$\mathrm{R} 2$ & 2012 年 4 月 & - \\
$\mathrm{R} 3$ & 2013 年 9 月 & - \\
\hline
\end{tabular}


時間の短縮の効果を感じさせる 1 番目の回答より, 書き換えエデイタは「書き換えの停 滞」の解消に効果的であったことが伺える．また，2 番目の回答は「平易化レベルの保 証」が実現できていることを示唆している。この他

・ 自分の書き換えを他の作業者が参照すると思うと責任を持って書くようになる という回答もあり，品質維持の動機につながっていることを伺わせる回答もあった。一 方, システムがなければ

・ NHK のニュースという枠にとらわれずによりやさしくできる可能性がある という指摘もあった。 なお，書き換え時間が短くなったという回答はあったが，日々の 作業時間が短くなっているわけではない，事情を質問したところ，

- 日々の作成本数が決まっているので書き換えに割り当てている総時間は変えてお らず，書き換えの質を向上させるための記者と日本語教師との検討，事前のリサー チに時間を費やしている

とのことであった。すなわち，書き換えエデイタによって質の向上のための時間が生み 出されていると考えられる.

（2）書き換えエディタのさまざまな機能, 用例検索の機能, 読解補助情報エディタを使うこ とによる副作用（例えば書き換えが画一的になるなど）はないでしょうか.

・「前もこう言い換えた」は一見安全が保護されているように見えるが絶えず再検 討しなければならないだろう（他類似回答 3 件）.

全員上記のように過去用例を安易に再利用すべきでないという自覚があり，現在は問題 ないと回答していた。類似した回答に

・（自分の書き換えに対して）日誌に次回はチャレンジすることなどと引き継ぎし ている

・ 参加した 1 年目は先輩の用例に従わなければと思い达んでいたが, 現在は他の分 かりやすい表現を探している

などがあり，常に新しい表現を模索している姿勢が伺えた。書き換えエディ夕の支援機 能や読解補助エディタへのコメントはなく, 副作用は特にないと考えられる.

(3) 書き換えエディタのさまざまな機能, 用例検索の機能, 読解補助情報エディタはやさし い日本語の学習や NEWS WEB EASY の新人への教育に有用でしょうか.

・ 用例検索は NEWS WEB EASY の書き換えスタッフの養成には有用（他類似回答 3 件).

・ 用例検索の記事にはニュースの特有の表現があるので他（のやさしい日本語）で は有用とは言えない（他類似回答 1 件).

途中から NEWS WEB EASY の制作に参加した日本語教師からは

・いろいろなルールがそれぞれのシステムに反映されているので, 意識しながら（ルー 
ルを）身に付けることができた

との回答があった。この回答は語の難易度, 文長の制限, NHK での漢字の読みなどがシ ステムで提示されることを指している。一方, 別の日本語教師からは新人の教育に有用 と回答した上で

・ システム操作に日本語教育と無関係な専門用語が多いので覚えるのに負担がかか る可能性がある

との指摘があった，例えば，新たな書き換え稿の作成ボタンに使われている「make child」 （書き換え履歴の木構造の子ノード作成の意味）といった専門用語が分かりにくさにつな がるという指摘である.

\subsection{2 書き換えエディタ}

書き換えエディタの 10 の機能について，それぞれの「使用頻度」「有用性」「満足度」を 5 段 階の選択肢で質問した，使用頻度と有用性は機能そのものについて，満足度はインターフェー スについての質問である。 以後も同じ趣旨で質問した。

例として「履歴」についての問いを表 2 に，回答に使った 5 段階の選択肢を表 3 に示す.

さらに, それぞれの機能についてコメント, 使用状況, 使用状況の変化について自由記述で 回答してもらった，全員の選択結果を表 4 に示す。な打「箱による編集」は必ず使用するため 使用頻度の質問はしていない. 表 4 の「日教師」の列は日本語教師 J1 から J4 の結果を示す. 同様に「記者」の列は記者 R1 から R3 の結果を示す.

まず個人に着目する。記者 R3 の使用頻度を他の記者と比べると 5 がかなり多い．記者 R 3 が

表 2 「履歴」情報に関する問い

\begin{tabular}{ll}
\hline & $\begin{array}{l}\text { 書き換えエディタでは元記事から始まる履歴をすべて記録しています. } \\
\text { 履歴情報について伺います. }\end{array}$ \\
\hline 使用頻度 & この情報はどれくらいの記事の書き換えで使っていますか. \\
有用性 & この情報は役に立っていますか. \\
満足度 & この情報の提示に仕方に満足ですか. \\
\hline
\end{tabular}

表 3 選択肢

\begin{tabular}{clll}
\hline 選択肢 & \multicolumn{1}{c}{ 使用頻度 } & \multicolumn{1}{c}{ 有用性 } & \multicolumn{1}{c}{ 満足度 } \\
\hline 1 & $80 \%$ 以上 & 役に立っている & 満足 \\
2 & $60 \%$ から $80 \%$ & やや役に立っている & やや満足 \\
3 & $40 \%$ から $60 \%$ & どちらとも言えない & どちらとも言えない \\
4 & $20 \%$ から $40 \%$ & あまり役に立っていない & やや不満 \\
5 & $20 \%$ 以下 & 役に立っていない & 不満 \\
\hline
\end{tabular}


表 4 書き換えエディタの選択結果

\begin{tabular}{|c|c|c|c|c|c|c|}
\hline 機能 & 質問項目 & 日教師 & 日教師平均 & 記者 & 記者平均 & 全平均 \\
\hline \multirow{3}{*}{$\begin{array}{l}\text { 履歴 } \\
(\text { 書き換え原稿) }\end{array}$} & 使用頻度 & $1,1,1,1$ & 1.00 & $1,1,5$ & 2.33 & 1.57 \\
\hline & 有用性 & $1,1,1,1$ & 1.00 & $1,1,3$ & 1.67 & 1.29 \\
\hline & 満足度 & $1,1,1,1$ & 1.00 & $1,1,3$ & 1.67 & 1.29 \\
\hline \multirow[t]{2}{*}{ 箱による編集 } & 有用性 & $1,1,1,1$ & 1.00 & $1,1,1$ & 1.00 & 1.00 \\
\hline & 満足度 & $2,1,2,1$ & 1.50 & $1,1,2$ & 1.33 & 1.43 \\
\hline \multirow[t]{3}{*}{ 文長表示 } & 使用頻度 & $1,1,1,1$ & 1.00 & $1,1,1$ & 1.00 & 1.00 \\
\hline & 有用性 & $1,1,1,1$ & 1.00 & $1,1,1$ & 1.00 & 1.00 \\
\hline & 満足度 & $1,1,1,1$ & 1.00 & $1,1,1$ & 1.00 & 1.00 \\
\hline \multirow[t]{3}{*}{ 語難易度表示 } & 使用頻度 & $1,1,1,1$ & 1.00 & $1,3,5$ & 3.00 & 1.86 \\
\hline & 有用性 & $1,1,1,1$ & 1.00 & $1,2,3$ & 2.00 & 1.43 \\
\hline & 満足度 & $2,1,2,1$ & 1.50 & $2,1,3$ & 2.00 & 1.71 \\
\hline \multirow[t]{3}{*}{ コメント欄 } & 使用頻度 & $2,2,2,1$ & 1.75 & $5,3,5$ & 4.33 & 2.86 \\
\hline & 有用性 & $1,1,2,1$ & 1.25 & $2,1,3$ & 2.00 & 1.57 \\
\hline & 満足度 & $2,1,2,1$ & 1.50 & $2,1,3$ & 2.00 & 1.71 \\
\hline \multirow[t]{3}{*}{ 単一原稿画面 } & 使用頻度 & $1,1,1,1$ & 1.00 & $3,1,5$ & 3.00 & 1.86 \\
\hline & 有用性 & $1,3,1,1$ & 1.50 & $2,1,3$ & 2.00 & 1.71 \\
\hline & 満足度 & $1,3,1,1$ & 1.50 & $2,1,3$ & 2.00 & 1.71 \\
\hline \multirow[t]{3}{*}{3 原稿比較画面 } & 使用頻度 & $1,1,1,1$ & 1.00 & $5,1,1$ & 2.33 & 1.57 \\
\hline & 有用性 & $1,2,2,1$ & 1.50 & $3,1,2$ & 2.00 & 1.71 \\
\hline & 満足度 & $1,2,3,1$ & 1.75 & $1,1,1$ & 1.00 & 1.43 \\
\hline \multirow[t]{3}{*}{ 原稿難易度表示 } & 使用頻度 & $1,1,1,1$ & 1.00 & $1,1,3$ & 1.67 & 1.29 \\
\hline & 有用性 & $1,1,1,1$ & 1.00 & $1,1,2$ & 1.33 & 1.14 \\
\hline & 満足度 & $1,1,2,1$ & 1.25 & $1,1,2$ & 1.33 & 1.29 \\
\hline \multirow[t]{3}{*}{ 文の重複画面 } & 使用頻度 & $5,5,5,5$ & 5.00 & $5,5,5$ & 5.00 & 5.00 \\
\hline & 有用性 & $4,4,5,3$ & 4.00 & $3,4,3$ & 3.33 & 3.71 \\
\hline & 満足度 & $3,3,3,3$ & 3.00 & $3,3,3$ & 3.00 & 3.00 \\
\hline \multirow[t]{3}{*}{ 原稿差分画面 } & 使用頻度 & $1,1,1,1$ & 1.00 & $2,1,5$ & 2.67 & 1.71 \\
\hline & 有用性 & $1,1,1,1$ & 1.00 & $1,1,3$ & 1.67 & 1.29 \\
\hline & 満足度 & $1,1,2,1$ & 1.25 & $1,1,3$ & 1.67 & 1.43 \\
\hline
\end{tabular}

1 をつけているのは「文長表示」と「3 原稿比較画面」で, この他では「原稿難易度表示」に 3 をつけているのみである。他の記者と比較してみよう。記者 R3 の使用頻度が 5 で他の記者が 1 あるいは 2 を付けている項目は, 「履歴」「語難易度表示」「単一原稿画面」「原稿差分画面」で ある。「履歴」と「原稿差分画面」は日本語教師との共同作業で使うため，日本語教師が使えば 情報を共有できる。「単一原稿画面」については，代わりに「3 原稿比較画面」を使っていると のコメントがあった．また「語難易度表示」は表現の平易化に使う機能であるため使っていな いとのことであった， 6.1 .2 項で述べたように，当初記者は表現の平易化を担当しないという原 則を設けており，それに対応したコメントと思われる。以上を総合すると記者 R3 は求められ 
ている仕事に専念している度合いが他の記者より強いことが伺える。

次に各項目を概観する。「履歴」はよく使われ，有用性，満足度も高い。作業中の使い方には

・ 書き換えの各段階での情報の抜け落ちの確認

- 2 つの書き換え案があるときに両方を作って検討

・ 編集責任者との確認で削除した情報を復活する場合に使用

という回答があった。履歴は木構造で表現しているため兄弟ノードの原稿を作ることができる. 上述の 2 つの書き換え案は兄弟ノードを利用して作成している。また，作業の事前事後の使い 方には

・ 微妙な外交問題などをどのように書き換えているかなどを観察する

・ 日誌を書く際の作業の振り返りに使用

との回答があった。事前のリサーチ，振り返りにも活用されている.

「箱による編集」も有用性, 満足度とも高い。一方

・ 元記事の文数に固定されている箱の数を増やせるようにしてほしい

との要望があった。元記事の構成を大幅に変更した場合などに不便なようである.

「文長表示」は全員がすべての項目に 1 を付与している，人間が文字数を数えて確認するに は大きな手間がかかる，文字数の計算は単純だが，効果の高い指標と考えられる，また，「文長 表示」は編集責任者へ書き換えを説明する際に使われていた.

「語難易度表示」は日本語教師の評価が高い. 記者 R1, R2 も積極的にこの指標を利用して いる.

・ 全体が色で表示されているため記事中の語彙難易度の状況が一目で把握できる点が良い

・学習機能により難易度の精度が上がった

という回答があった。「語難易度表示」も編集責任者への説明に利用されている。なお，記者の

・最近では難しい単語はだいたい分かるようになったため以前ほどこの表示に頼らなく なった

という回答もあった。

「コメント欄」については書き込みの頻度を尋ねたため, 記者の使用頻度は低いが, 有用性 は高いという評価である。主に日本語教師が書き込んでおり，内容は

・ 参考情報の出典（Web サイトなど）

- 書き換えの意図の説明

- 複数案あるときの代替案

- 不明点

などである。記者からは

- 日本語教師の書き換えプランが理解できる

・代替案をコピーできる 
といった回答があった。なお

・コメントが入っていない文の欄は非表示にしたい

との要望も寄せられた。表示方法には工夫の余地がある.

「単一原稿画面」と「3 原稿比較画面」はどちらも書き換え原稿の表示であり，一方だけ使っ ている作業者，目的に応じて使い分けている作業者がいた。それぞれ使い方を決めており，両 者は必要な機能となっていた。

「原稿難易度表示」も利用頻度, 有用性, 満足度とも高い.

・原稿難易度を目標に書き換える

・記者や編集責任者に書き換えの必要性を説明するときに使う

という回答があった。原稿難易度を書き換えの目標に使っているという回答に関して, 現在, 原稿難易度と外国人理解度との詳細な関係は分かっておらず，今後調査が必要である。

「文の重複画面」と「原稿差分画面」はどちらも単純な最長共通文字列検出アルゴリズムを 利用している。「文の重複画面」は主に記者の要約する作業を支援する目的で作成しているため 日本語教師は使っていない。 また記者からは

・記事を読むと重複箇所はだいたい分かるので使っていない

という回答を得た。一方「原稿差分画面」は使用頻度, 有用性, 満足度とも高い. 特に修正箇所 が少なくなり目視での書き換え稿間の差の確認が難しくなる後半で使われている. 直前稿との 差の確認, 編集責任者への変更箇所の説明, 最終的な夕イポの発見などが主要な使い方である.

・ 日本語教師との「キャッチボール」17に欠かせない

という記者のコメントもあった。「原稿差分画面」も単純だが有用な機能である.

\subsection{3 用例検索機能}

用例検索機能について，全員に選択肢と自由記述形式で質問した。選択肢は書き換えエディ 夕と同じ使用頻度, 有用性, 満足度に加えて, 用例の蓄積の重要性について尋ねた。質問は「用 例の蓄積は重要でしょうか」である。また回答は「1:重要, 2 :やや重要, 3:どちらとも言えない, 4:あまり重要でない，5:重要でない」の 5 段階である。結果を表 5 に示す。記者 R1の使用頻度 は低いが, この項目以外の評価は高い. 記者 $\mathrm{R} 1$ は自分では使わないが日本語教師が検索した 結果を利用しているとコメントしており，有用性は高いと評価している.

用例の蓄積の重要性についても高い重要性を認めている.

さらに, 以下の自由記述形式の質問を行った。質問趣旨と主な回答を記す.

(1) 用例検索を使う目的とタイミングを教えてください.

- 書き換え前に参考になる記事を探す（他類似回答 4 件）

17 記者と日本語教師で行う原稿の確認のこと. 
表 5 用例検索の選択結果

\begin{tabular}{c|c|c|c|c|c|c}
\hline 機能 & 質問項目 & 日教師 & 日教師平均 & 記者 & 記者平均 & 全平均 \\
\hline 用例検索 & 使用頻度 & $1,1,1,1$ & 1.00 & $5,1,2$ & 2.67 & 1.71 \\
& 有用性 & $1,1,1,1$ & 1.00 & $1,1,1$ & 1.00 & 1.00 \\
& 満足度 & $1,1,2,1$ & 1.25 & $3,1,1$ & 1.67 & 1.43 \\
\hline 記事蓄積 & 重要性 & $1,1,1,1$ & 1.00 & $2,1,1$ & 1.33 & 1.14 \\
\hline
\end{tabular}

- 書き換え中に表現の書き換え例を探す（他類似回答 5 件）

- 作業外の時間で他の人が担当した記事を勉強する（他類似回答 2 件） 想定の通り，作業中に書き換え表現を探す用途が多い。また

・当日の記事の選択時に過去との重複を調べる用途

- 編集責任者の説明に過去の書き換え事例を示す目的

という回答もあった。

(2) どのような表現を入力しますか.

- 固有名詞

人名関連（マララさん，ウルトラマン), 組織名（IOC， IS イスラミックステート）

- 専門用語

気象災害用語（豪雨，土砂崩れ，孤立状態，浸水)，科学技術用語（AI，大気，生 存率, GPS), 文化・伝統関連用語（恵方巻き, かつお節, こいのほり，土用の丑 の日), 医療関係（手足口病，小頭症）

- 難しい表現

2 級以上の語彙，使わざるを得ない受け身や使役の使用例（行われる, やめさせ る,やめさせられる)

固有名詞は書き換えないが, 加える説明を調べるために入力して調査する．また，関連 記事を検索する場合にもキーワードとして入力している。専門用語は書き換え事例，お よび追加する説明を調査するために入力している.

（3）現在の用例検索は記事単位，もしくは文単位で検索結果が表示されます。この代わりに, 「避難」に対して「逃げる」といったフレーズの辞書を作って検索することが考えられま す。現在の方式とどちらが有用でしょうか.

・同じ単語でも記事の内容によって書き換え方は異なるので文や記事が必要（他類 似回答 5 件)

・どちらでも有用だが辞書ができるのだろうか

基本的には書き換え時に文脈，記事の全体を見るため現在の方式の方を有用と考えてい る. 特に, 現在は元記事とやさしい日本語の文を対応させて検索結果を表示できるため, 
元記事の表現が省略されたことが分かるようになっている。このため

・ある表現が文脈によって省略されやすい事実が分かる点が有用 という回答もあった。

(4) 検索システムの用例が蓄積され検索できる記事や表現が増えています。このような効果 を感じますか. あるいはまだ，蓄積が足りないと感じますか.

・ 蓄積効果を感じている（全員）

・同じ言い回しでも異なる書き換えがあるため蓄積はまだ必要（他類似回答 1 件）

・不足していると感じることがある

・不足はあまり感じない

・蓄積が進んだため，検索結果が多すぎたり，誤った結果が含まれたりすることが ある（他類似回答 1 件）

用例の蓄積効果は全員感じていた。ただし 7.1.1 項の (2) で報告したシステム全体につい ての副作用のアンケートの回答にあったように，無条件に使ってはいけないという意識 は強い. また, 現在記事数が 4,000 件を超えており, 過剩な検索結果, 不適切な検索結果 が問題になりつつあることが分かった.

\subsection{4 読解補助情報エディタ}

読解補助情報エディタについて日本語教師に選択形式と自由記述形式で質問した。選択肢は 5 段階でこれまでと同様である。また記者は作業を担当しないため質問していない.

選択肢問題の質問趣旨は以下の通りである.

(1) 読解補助情報エディタの使い勝手はいかがですか

(2) 以前の読解補助情報エデイ夕には学習機能がありませんでしたが現在はこれが装備され ています。学習機能は重要でしょうか

(3) 学習機能の性能に満足ですか

結果を表 6 に示す。現在の使い勝手, 学習機能とも満足度, 重要性とも大きい結果となった。ま た問題点，コメントを自由記述形式で求めたところ

・学習機能には大変助かっており性能にも概ね満足している.ただし自動推定された結果 から誤りを探すのが大変であり, 候補を出す方式の方が良いかもしれない

表 6 読解補助情報エデイタの選択結果

\begin{tabular}{l|c|c|c}
\hline \multicolumn{1}{c|}{ 対象 } & 質問項目 & 日教師 & 日教師平均 \\
\hline 使い勝手 & 満足度 & $1,1,2,1$ & 1.25 \\
学習機能 & 重要性 & $1,1,1,1$ & 1.00 \\
学習機能の性能 & 満足度 & $1,1,2,1$ & 1.25 \\
\hline
\end{tabular}


表 7 読解補助情報付与の時間

\begin{tabular}{llll}
\hline & $\mathrm{J} 1$ & \multicolumn{1}{c}{$\mathrm{J} 2$} & \multicolumn{1}{c}{$\mathrm{J} 3$} \\
\hline 学習機能ありの現在の平均作業時間 & 10 分 & 10 分 & 5 分から 10 分 \\
学習機能なしの場合 & 3 倍 & 2 倍から 3 倍 & 1.5 倍程度 \\
\hline
\end{tabular}

という回答が 1 件あった。現在は誤り率 $5 \%$ 程度だと推定しているが，この程度になると誤りを 見過ごしやすくなる問題がある。自動推定結果をまとめて修正するのでなく，回答のように候 補を出して選択させる方式も検討したい.

次に，読解補助情報エディタの学習機能によりどれくらい作業時間が短縮されたかを調査す るため次の質問を行った18.

（1）現在の 1 記事あたりの読解補助情報の付与の時間はどれくらいですか. また学習機能が ないころは何倍くらい時間がかかっていましたか.

この質問は学習機能のないエディタでの作業を経験している日本語教師 J1, J2, J3 に対しての み実施した。結果を表 7 に示す。日本語教師はおよそ類似した感覚を持っていることが分かっ た. 学習機能付きの場合の 1 記事の処理時間がおよそ10 分で, 学習機能がない場合にはその最 大 3 倍の処理時間がかかったという結果が得られた。 なお, この質問は, 過去と現在の比較と なるため, 結果には作業者自身の学習効果を含んでおり, 単純に学習機能だけの効果と言えな い点に注意が必要である。

\section{2 口グの分析}

7.1.1 項の書き換えエディタのアンケート (1) では「書き換えの停滞」と「平易化レベルの保 証」に対する効果が示唆されたことを述べた，本節では効果をさらに確認するため書き換え工 ディタのログを解析した．対象としたのは NEWS WEB EASY 開始の 2012 年 4 月から 2016 年 11 月までのログである。書き換えエディタのログは本来，本節で述べるような調査を目的に設 計されていない，そこで，以下ではできるだけ安定していると思われるデータを抽出して解析し た. この期間で元記事から完成まで普通に制作されたと推定できる記事は 4,164 件であった ${ }^{19}$.

\subsection{1 記者と日本語教師の平均ターン数}

やさしい日本語のニュースは元記事を記者と日本語教師が交代で記事を書き換えて作成する。 書き換え稿の数, ターン数は 6.1 .1 項で述べた書き換えの停滞, あるいは逆数を取ると日本語教

\footnotetext{
18 読解補助情報エディタにはログ機能がないためアンケートで質問した.

19 複数の日本語教師, あるいは記者が携わった記事, 完成に至らなかった記事, 原稿の系列のタイムスタンプに逆転 が見られた記事を除外した。
} 
師と記者の互いの仕事への理解度合いの指標になると考えた。 そこで, 上記の 4,164 記事から, 典型的と考えられる

$$
\text { 記者 } \rightarrow(\text { 記者 } \mid \text { 日本語教師 })^{\star} \rightarrow \text { 編集責任者確認用 }
$$

のパターンに従って書き換えられた記事 3,215 本を抽出した. そして各記事の最初の記者の書 き換えから編集責任者確認用までの書き換え稿の数を算出し，これをターン数として月ごとに 平均を計算した。通常, 最短で「記者 $\rightarrow$ 日本語教師 $\rightarrow$ 編集責任者確認用」の3つの書き換え 稿, すなわち 3 ターンが必要となる.

図 6 に結果を示す. NEWS WEB EASY 開始時の 2012 年 4 月の平均夕ーン数は 5 に近いが 半年後の 2012 年 10 月には 3 近くにまで減少し, その後同じような数が続いている。すなわち, 開始から半年程度で停滞が減少，あるいは互いの仕事への理解が深まったことを示唆している と考える ${ }^{20}$. アンケートの結果と本項の結果より，書き換え支援システムは書き換えの停滞の 解消に効果があったと考える.

\subsection{2 平易化レベルの保証}

平易化レベルの保証に対する書き換えエディタの効果は, 文長と難語率を元記事とやさしい 日本語のニュースで比較することでおよそ評価できる。そこで，各月の平均文長と平均難語率

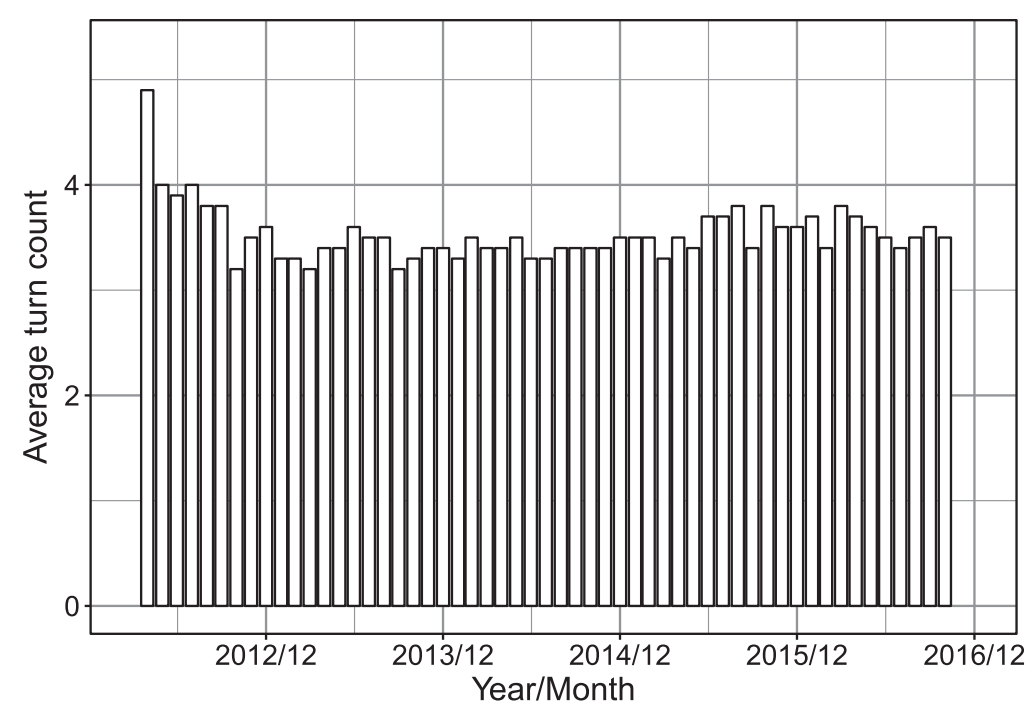

図 6 平均夕ーン数

\footnotetext{
20 記事の書き換え時間のログの分析も試みたが，1 日の制作記事数が決まっていて，制限時間内であれば時間をかけ
} られること, 待ち時間, 休䟤時間などの影響が見積もれないことから解析は困難と考え実施しなかった。 
を日本語教師ごとに調査した。調査した記事は全 4,164 件である。また日本語教師はこの期間, 延べ 5 名が制作に関わったため，全員について上記の平均を計算した，平均文長と難語率の結 果を図 7 および図 8 に示す。図の左が元記事，右がやさしい日本語のニュースである。

2 つの図を見ると，平均文長，平均難語率ともやさしい日本語のニュースの方が元記事より 明らかに小さくなっている。またやさしい日本語の平均文長と平均難語率は，すべての日本語

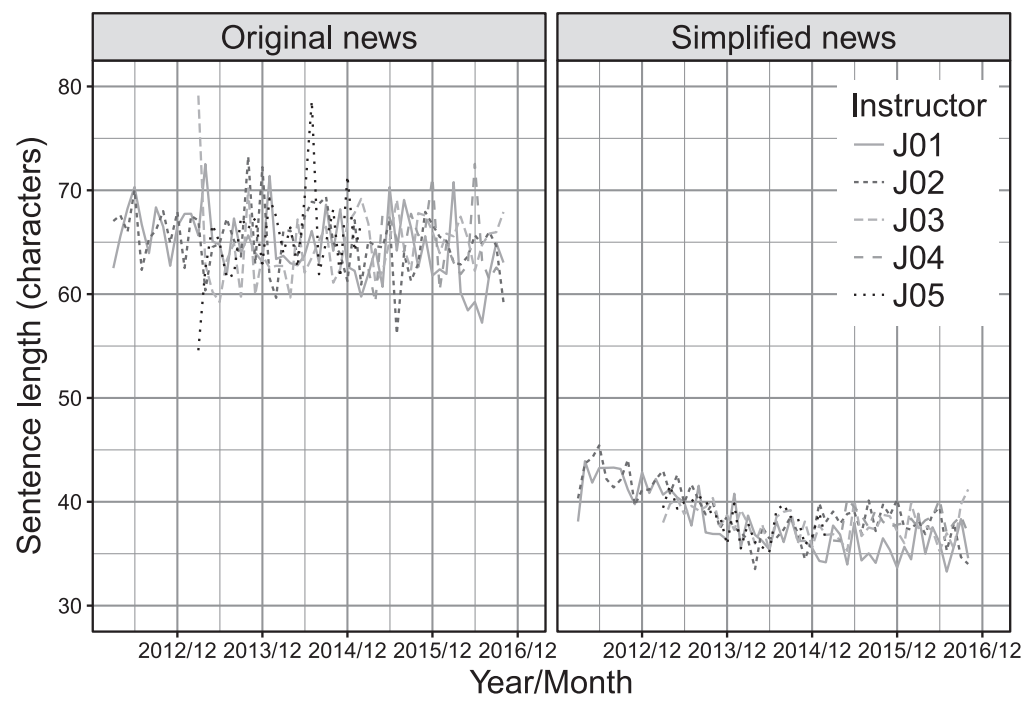

図 7 平均文長

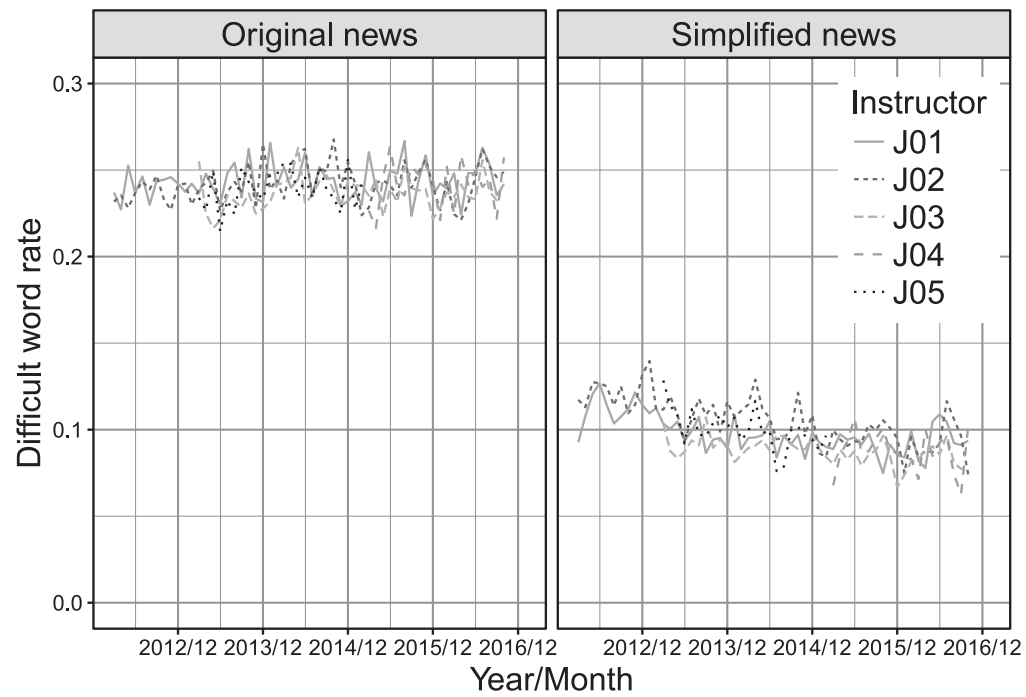

図 8 平均難語率 
教師で似た值となっている。これらの結果は平易化レベルの保証に書き換えエデイタが効果的 であったことを示したものと考える。

さらに図 7 の平均文長と図 8 の平均難語率のやさしい日本語（右部分）のグラフの横軸方向 の変化を観察すると，両者とも特に初期に右下がりの傾向を示している．7.1.1 項の書き換え支 援システムの全体のアンケート (2) で担当者は常に書き換えの改善を目指しているという回答 を得ており，グラフの右下がり傾向は日本語教師が文長と難語率を強く意識しながら日々書き 換えの改善を試みていることの現れと思われる.

\section{8 議論}

アンケートでは書き換えエディタと読解補助情報エディタの機能のほとんどが高頻度に使わ れていること，また日本語教師，記者ともに有用性を高く評価していることを示す回答を得た. ターン数のログ解析では，書き換えが初期に比べてよりスムーズに進むようになり，書き換え の停滞の問題が軽減されたこと, 平均文長と平均難語率の分析では, 両者とも元記事より大幅 に減少し，平易化レベルの保証が実現できていたことを確認した。

今後, 新たにやさしい日本語を使った情報提供を行う場合に有用と思われる点を指摘したい. 1 点目は学習機能である。ふりがななどの読解補助情報, 語の難易度推定に学習機能を入れ て以来，2つのエディタとも特段の保守なしに順調に運用されている．アンケートでも学習機 能の効果は高い評価を得た。日々繰り返す作業に自動システムを導入する場合，学習機能は特 に高い効果をもたらすと考える。

2 点目は用例の利用である。書き換えエディタの用例検索機能は記事数が増え, 有用性が増 していることが明らかになった，用例は積極的に利用すべきと考える．ただし，用例検索を利 用することは 6.1 .3 項で述べたように書き換え原則の開発をユーザが主体的に行うことにつなが る。あらかじめ書き換え原則を網羅的に準備できず，ユーザに原則の書き換えを任せてよい場 合には用例検索機能は有用と考える.

3 点目は書き換えの説明のしやすさである，当初，記者と日本語教師の共同作業を支援する ため, コメント追加，記事の履歴の保存などの機能を設けた．これらの機能は互いの書き換え の説明の材料になると考えたからである，次に詳述するように，記者と日本語教師の理解が進 んだ結果, 彼らの間の説明の必要性はある程度減っているようである。一方, 編集責任者など 他の参加者への説明はコメント，履歴などを使って引き続き行われている，書き下ろしでなく 元文書を書き換える場合，元文書の作者に説明が必要な場合は多いと考える。また，放送局の ように最終的な責任者がいる場合その人への説明も必要となる。書き換えの説明をしやすいシ ステムにしておくのが1つの要点と考える.

最後に日本語教師と記者の相互の理解の深まりから見たシステムの今後について触れたい. 
アンケートによると開始から 5 年を経て日本語教師と記者の互いの知識の理解が進んだことが 明らかになった，例えば，語難易度表示に関する記者へのアンケートに

・最近では難しい単語はだいたい分かるようになったため以前ほどこの表示に頼らなく なった

という回答があったことを 7.1 .2 項で述べた。 また日本語教師への追加質問では

・ ニュースの構成がそのままではやさしくしにくい時, 積極的に構成の変更を提案するよ うになった

という回答を得た．いずれも相互理解が進んだことを示唆している．さらに 7.2 .1 項の平均ター ン数の分析では, 相互理解が NEWS WEB EASYの開始から半年程度の間に進んだことを示唆 する結果を得た。

記者がやさしい日本語に十分慣れれば，ボーイングの事例と同じく，専門家である記者がシス テムの指摘に従って書き換えを進めることが可能になると考える。ただし，新たに担当する記 者に，いかにやさしい日本語の知識を伝えるかが問題となる。知識の伝達に関して，過去に日 本語教師が 1 名交代したことがある。新たに参加した日本語教師からは，用例を使ってニュー スのやさしい日本語を学習したとのアンケートの回答があった．新しい日本語教師と同様に記 者が過去の用例を使ってやさしい日本語を学習することは可能だろう.

\section{9 おわりに}

本稿では NHK のやさしい日本語のニュースの Web サイト NEWS WEB EASY の概要, やさ しい日本語の書き換え原則を説明し, 続いてやさしい日本語のニュースの制作の体制とプロセ ス，および制作を支援する書き換えエディタと読解補助情報エデイタを報告した，書き換えエ ディタは日本語教師と記者という互いに異なる専門知識を持つ作業者が, 専門性を相互補完し ながらニュースをやさしい日本語に書き換えるエディタである。書き換えエディタには難しい 語を指摘する機能があり，ユーザは難しい語の書き換え候補を日々の運用で蓄積された書き換 え用例から検索することができる。読解補助情報エディタは漢字のふりがな, 辞書付与のため の語彙の難易度情報などを自動的に付与する機能を持つ。また自動付与した結果を人手で修正 するとその結果を学習することができる。これらのエディタは日々の運用によって用例が蓄積 され，学習が進むと性能が向上していく特徵を有している.

また，2つのエディタのユーザである日本語教師と記者を対象に，使用頻度，有用性，満足度 をアンケートで調査した結果，どちらのエディタも高い評価を得たことを報告した。またログ 解析により表現が平易になっていること，平易化は個人によらず同じ程度あったことなどを報 告した。 


\section{謝 辞}

本研究を進めるにあたってご協力いただいた NEWS WEB EASY の制作を担当している記者 OB および日本語教師の皆様，および，書き換えエディタ，および読解補助情報エディタを日々 運用して NEWS WEB EASY のサービスを実施している NHK 報道局ネットワーク報道部の皆 様に感謝します。また日頃より研究の進め方のご指導をいただく放送技術研究所ヒューマンイ ンターフェース研究部岩城正和部長，議論していただく同部のみなさまに感謝します。

\section{参考文献}

Barzilay, R. and Elhadad, N. (2003). "Sentence Alignment for Monolingual Comparable Corpora." In Proceedings of the 2003 Conference on Empirical Methods in Natural Language Processing (EMNLP 2003), pp. 25-32.

Bott, S. and Saggion, H. (2012). "Automatic Simplification of Spanish Text for e-Accessibility." In Proceedings of the 13th International Conference on Computers Helping People with Special Needs (ICCHP 2012), pp. 527-534.

Carroll, J., Minnen, G., Pearce, D., Canning, Y., Devlin, S., and Tait, J. (2009). "Simplifying Text for Language-Impaired Readers." In Proceedings of the 9th Conference of the European Chapter of the Association for Computational Linguistics (EACL 2009), pp. 269-270.

Chandrasekar, R., Doran, C., and Srinivas, B. (1996). "Motivations and Methods for Text Simplification." In Proceedings of the 16th International Conference on Computational Linguistics (COLING 1996), Volume II, pp. 1041-1044.

Coster, W. and Kauchak, D. (2011). "Simple English Wikipedia: A New Text Simplification Task." In Proceedings of the 49th Annual Meeting of the Association for Computational Linguistics: Human Language Technologies, pp. 665-669.

Goto, I., Tanaka, H., and Kumano, T. (2015). "Japanese News Simplification: Task Design, Data Set Construction, and Analysis of Simplified Text." In Proceedings of MT Summit XV, Vol. 1, pp. 17-31.

Hoard, J. E., Wojcik, R., and Holzhauser, K. (1992). "An Automated Grammar and Style Checker for Writers of Simplified English." In Holt, P. O. and Williams, N. (Eds.), Computers and Writing State of the Art, Chap. 19, pp. 278-296. Kluwer Academic Publishers.

Inui, K., Fujita, A., Takahashi, T., and Iida, R. (2003). "Text Simplification for Reading Assistance: A Project Note." In Proceedings of the 2nd International Workshop on Paraphrasing (PARAPHRASE 2003), pp. 9-16. 
庵功雄（編）(2010). 日本語これだけ！1.ココ出版.

庵功雄（編）(2011). 日本語これだけ！2.ココ出版.

庵功雄 (2016). やさしい日本語一多文化共生社会へ. 岩波新書. 岩波書店.

庵功雄，岩田一成，森篤嗣 (2009).「やさしい日本語」を用いた公文書の書き換え. 2009 年度

日本語教育学会秋季大会, pp. 135-140.

伊藤彰則, 鹿嶋彰, 前田理佳子, 水野義道, 御園生保子, 米田正人, 佐藤和之 (2008). 「やさし

い日本語」作成支援システムの試作. 平成 20 年度電気関係学会東北支部連合大会, p. 209 . 岩田一成 (2010). 言語サービスにおける英語指向一「生活のための日本語調査：全国調査」結

果と広島の事例から一. 社会言語学, 13 (1), pp. 81-94.

Jonnalagadda, S., Tari, L., Hakenberg, J., Baral, C., and Gonzalez, G. (2009). "Towards Effective

Sentence Simplification for Automatic Processing of Biomedical Text." In Proceedings of

Human Language Technologies: The 2009 Annual Conference of the North American Chapter

of the Association for Computational Linguistics, pp. 177-180.

梶原智之, 山本和英 (2015). 日本語の語彙平易化システムの構築. 情報処理学会第 77 回全国大

会, 2 巻, pp. 167-168.

河原俊昭, 野山広 (2007). 外国人住民への言語サービス. 明石書店.

国際交流基金，日本国際教育協会 (2007). 日本語能力試験出題基準 改訂版. 凡人社.

Kuhn, T. (2014). "A Survey and Classification of Controlled Natural Language." Computational Linguistics, 40 (1), pp. 121-171.

熊野正, 後藤功雄, 田中英輝, 浦谷則好, 江原暉将 (2001). 翻訳用例提示システムの設計・開

発・運用. 電子情報通信学会, J84-D-II (6), pp. 1175-1184.

熊野正, 田中英輝 (2014). Dependent Dirichlet Process を用いた日本語文書へのタグづけのオ

ンライン学習. 言語処理学会第 20 回年次大会, pp. 1075-1078.

熊野正, 田中英輝 (2016). 統計機械翻訳によるやさしい日本語書き換えの性能向上. 言語処理学 会第 22 回年次大会, pp. 713-716.

松田真希子 (2010). やさしい日本語への自動言い換えシステムの開発. 2010 年度日本語教育学 会春季大会予稿集, pp. 91-93.

Mitamura, T. and Nyberg, E. (2001). "Automatic Rewriting for Controlled Language Translation." In Proceedings of the NLPRS 2001 Workshop on Automatic Paraphrasing: Theory and Application, pp. 1-12.

Miwa, M., Sætre, R., Miyao, Y., and Tsujii, J. (2010). "Entity-Focused Sentence Simplification for Relation Extraction." In Proceedings of the 23rd International Conference on Computational Linguistics (COLING 2010), pp. 788-796.

Nelken, R. and Shieber, S. M. (2006). "Towards Robust Context-Sensitive Sentence Alignment 
for Monolingual Corpora." In Proceedings of the 11th Conference of the European Chapter of the Association for Computational Linguistics (EACL 2006), pp. 161-168.

野本忠司 (2016). リーダビリティー研究の 100 年. 情報処理学会研究会資料, 2016-DC-101 号, pp. 1-7.

Pressman, R. S. (2005). 実践ソフトウエアエンジニアリング. 日科技連.

佐藤和之 (2004). 災害時の言語表現を考える。日本語学, 23 (8), pp. 34-45.

Shardlow, M. (2014). "A Survey of Automated Text Simplification." International Journal of Advanced Computer Science and Applications (IJACSA), Special Issue on Natural Language Processing, pp. 58-70.

Siddharthan, A. (2002). "An Architecture for a Text Simplification System." In Proceedings of the Language Engineering Conference 2002 (LEC 2002), pp. 64-71.

Siddharthan, A. (2003). Syntactic Simplification and Text Cohesion. Ph.D. dissertation, University of Cambridge.

Siddharthan, A. (2014). "A Survey of Research on Text Simplification." International Journal of Applied Linguistics, 165 (2), pp. 259-298.

田近洵一 (編) (2011). 例解小学国語辞典 第 5 版. 三省堂.

田中英輝, 美野秀弥 (2010). やさしい日本語によるニュースの書き換え実験. 情報処理学会研究 会資料, 2010-NL-199-9 号, pp. 1-6.

田中英輝, 美野秀弥 (2016). ニュースのためのやさしい日本語とその外国人日本語学習者への 効果. 情報処理学会論文誌, 57 (10), pp. 2284-2297.

田中伊式 (2012). 「この事件は〜したものです」などの表現をめぐって. 放送研究と調査, pp. 72-82. Vickrey, D. and Koller, D. (2008). "Sentence Simplification for Semantic Role Labeling." In Proceedings of the 46th Annual Meeting of the Association for Computational Linguistics: Human Language Technologies (ACL-08: HLT), pp. 344-352.

Watanabe, W. M., Candido Jr., A., Uzêda, V. R. d., Fortes, R. P. d. M., Pardo, T. A. S., and Aluísio, S. M. (2009). "Facilita: Reading Assistance for Low-literacy Readers." In SIGDOC' 09 Proceedings of the 27th ACM International Conference on Design of Communication, pp. 29-36.

米倉律, 谷正名 (2012). 国内在住外国人のメディア環境とメディア行動—4 国籍の外国人向け電 話アンケート調査から一. 放送研究と調査 Aug., pp. 62-75.

\section{略歴}

田中 英輝 : 1982 年九州大学工学部電子工学科卒業. 1984 年同大学院修士課程 修了。同年 NHK 入局，1987 年放送技術研究所研究員。（株）国際電気通信基 
礎技術研究所 (ATR) 出向. 同音声翻訳通信研究所主任研究員, 音声言語コ ミュニケーション研究所室長を経て, 現在, 放送技術研究所ヒューマンイン ターフェース研究部上級研究員。テキストの平易化, 機械翻訳などの自然言 語処理の研究に従事. 博士 (工学).

熊野 正：1993 年東京工業大学工学部情報工学科卒業. 1995 年同大学院理工 学研究科情報工学専攻修了。同年 NHK 入局.（株）国際電気通信基礎技術研 究所 (ATR) 音声言語通信研究所および同音声言語コミュニケーション研究所 出向を経て, 現在, 放送技術研究所ヒューマンインターフェース研究部主任 研究員. 自然言語処理・音声言語処理の研究開発に従事.

後藤 功雄 : 1995 年早稲田大学理工学部電気工学科卒業. 1997 年同大学院理工 学研究科修士課程修了. 2014 年京都大学大学院情報学研究科博士課程修了. 博士 (情報学)。1997 年 NHK 入局, (株) 国際電気通信基礎技術研究所 (ATR) および国立研究開発法人情報通信研究機構出向を経て，現在，放送技術研究 所ヒューマンインターフェース研究部にて自然言語処理の研究に従事.

美野 秀弥： 2002 年東京工業大学情報理工学部計算工学科卒業. 2004 年同大学 院情報理工学研究科修士課程修了。同年 NHK 入局, 北見放送局, 国立研究 開発法人情報通信研究機構出向を経て, 現在, 放送技術研究所ヒューマンイ ンターフェース研究部研究員. 自然言語処理の研究に従事. 